University of Nebraska - Lincoln

DigitalCommons@University of Nebraska - Lincoln

Comparative Analysis of Edwardsiella Isolates from Fish in the Eastern United States Identifies Two Distinct Genetic Taxa Amongst Organisms Phenotypically Classified as E. tarda

\author{
Matt J. Griffin \\ Mississippi State University, griffın@cvm.msstate.edu \\ Sylvie M. Quiniou \\ USDA-ARS \\ Theresa Cody \\ Florida Fish and Wildlife Conservation Commission \\ Maki Tabuchi \\ Florida Fish and Wildlife Conservation Commission \\ Cynthia Ware \\ Mississippi State University \\ See next page for additional authors
}

Follow this and additional works at: https://digitalcommons.unl.edu/usdaarsfacpub

Griffin, Matt J.; Quiniou, Sylvie M.; Cody, Theresa; Tabuchi, Maki; Ware, Cynthia; Cipriano, Rocco C.; Mauel, Michael J.; and Soto, Esteban, "Comparative Analysis of Edwardsiella Isolates from Fish in the Eastern United States Identifies Two Distinct Genetic Taxa Amongst Organisms Phenotypically Classified as $E$. tarda" (2013). Publications from USDA-ARS / UNL Faculty. 1338.

https://digitalcommons.unl.edu/usdaarsfacpub/1338

This Article is brought to you for free and open access by the U.S. Department of Agriculture: Agricultural Research Service, Lincoln, Nebraska at DigitalCommons@University of Nebraska - Lincoln. It has been accepted for inclusion in Publications from USDA-ARS / UNL Faculty by an authorized administrator of DigitalCommons@University of Nebraska - Lincoln. 


\section{Authors}

Matt J. Griffin, Sylvie M. Quiniou, Theresa Cody, Maki Tabuchi, Cynthia Ware, Rocco C. Cipriano, Michael J. Mauel, and Esteban Soto 


\title{
Comparative analysis of Edwardsiella isolates from fish in the eastern United States identifies two distinct genetic taxa amongst organisms phenotypically classified as E. tarda
}

\author{
Matt J. Griffin ${ }^{\mathrm{a}, *}$, Sylvie M. Quiniou ${ }^{\mathrm{b}}$, Theresa Cody ${ }^{\mathrm{c}}$, Maki Tabuchi ${ }^{\mathrm{c}}$, \\ Cynthia Ware $^{\mathrm{a}}$, Rocco C. Cipriano ${ }^{\mathrm{d}}$, Michael J. Mauel ${ }^{\mathrm{e}}$, Esteban Soto ${ }^{\mathrm{f}}$ \\ ${ }^{a}$ Thad Cochran National Warmwater Aquaculture Center, College of Veterinary Medicine, Mississippi State University, Stoneville, MS, \\ United States \\ ${ }^{\mathrm{b}}$ Thad Cochran National Warmwater Aquaculture Center, Catfish Genetics Research Unit, USDA-ARS, Stoneville, MS, United States \\ ${ }^{\mathrm{c}}$ Florida Fish and Wildlife Conservation Commission, Fish and Wildlife Research Institute, St. Petersburg, FL, United States \\ ${ }^{\mathrm{d}}$ National Fish Health Research Laboratory, United States Geological Survey, Kearneysville, WV, United States \\ ${ }^{\mathrm{e}}$ Mississippi Veterinary Research and Diagnostic Laboratory, Mississippi State University, Pearl, MS, United States \\ ${ }^{\mathrm{f}}$ Department of Pathobiology, School of Veterinary Medicine, Ross University, Basseterre, St. Kitts, West Indies
}

\section{A R T I C L E I N F O}

Article history:

Received 1 October 2012

Received in revised form 8 March 2013

Accepted 23 March 2013

\section{Keywords:}

Blue catfish

Channel catfish

Edwardsiella tarda

Hybrid striped bass

Multilocus sequencing

Tilapia

PCR

rep-PCR

\begin{abstract}
A B S T R A C T
Edwardsiella tarda, a Gram-negative member of the family Enterobacteriaceae, has been implicated in significant losses in aquaculture facilities worldwide. Here, we assessed the intra-specific variability of $E$. tarda isolates from 4 different fish species in the eastern United States. Repetitive sequence mediated PCR (rep-PCR) using 4 different primer sets (ERIC I \& II, ERIC II, BOX, and GTG5) and multi-locus sequence analysis of $16 S$ SSU rDNA, groEl, gyrA, gyrB, pho, pgi, pgm, and rpoA gene fragments identified two distinct genotypes of $E$. tarda (DNA group I; DNA group II). Isolates that fell into DNA group II demonstrated more similarity to E. ictaluri than DNA group I, which contained the reference $E$. tarda strain (ATCC \#15947). Conventional PCR analysis using published E. tarda-specific primer sets yielded variable results, with several primer sets producing no observable amplification of target DNA from some isolates. Fluorometric determination of $\mathrm{G}+\mathrm{C}$ content demonstrated $56.4 \% \mathrm{G}+\mathrm{C}$ content for DNA group I, $60.2 \%$ for DNA group II, and $58.4 \%$ for E. ictaluri. Surprisingly, these isolates were indistinguishable using conventional biochemical techniques, with all isolates demonstrating phenotypic characteristics consistent with E. tarda. Analysis using two commercial test kits identified multiple phenotypes, although no single metabolic characteristic could reliably discriminate between genetic groups. Additionally, anti-microbial susceptibility and fatty acid profiles did not demonstrate remarkable differences between groups. The significant genetic variation $(<90 \%$ similarity at gyrA, gyrB, pho, phi and pgm; $<40 \%$ similarity by rep-PCR) between these groups suggests organisms from DNA group II may represent an unrecognized, genetically distinct taxa of Edwardsiella that is phenotypically indistinguishable from E. tarda.
\end{abstract}

(c) 2013 Elsevier B.V. All rights reserved.

\footnotetext{
* Corresponding author at: Thad Cochran National Warmwater Aquaculture Center, Mississippi State University, PO Box 197, 127 Experiment Station Road, Stoneville, MS 38776, United States.

E-mail address: griffin@cvm.msstate.edu (M.J. Griffin).
}

\section{Introduction}

Edwardsiella tarda, a Gram-negative, motile, rod-shaped bacterium, is the causative agent of edwardsiellosis in a wide variety of cultured fish and has been implicated in significant losses in aquaculture worldwide (Mohanty and Sahoo, 2007). First described from humans (Ewing et al., 
1965), it is the most widespread member of the Edwardsiella genera, having been reported from over 20 species of freshwater and marine fish from 25 countries in the Americas, Europe, Asia, Australia, Africa and the Middle East (Hawke and Khoo, 2004). In channel catfish, E. tarda is the causative agent of emphesematous putrefactive disease of catfish and was the first member of the genus described as a pathogen in channel catfish (Meyer and Bullock, 1973). Although traditionally considered less important than the closely related $E$. ictaluri, case submissions to the Aquatic Diagnostic Laboratory of the Thad Cochran National Warmwater Aquaculture Center in Stoneville, MS (http:// tcnwac.msstate.edu/publications.htm) suggest E. tarda is a potential emerging disease in catfish aquaculture in the southeastern United States.

Several studies have demonstrated a wide degree of intraspecific diversity for $E$. tard a from different geographic regions and host species, making the development of broad-spectrum molecular based diagnostic tools difficult (Castro et al., 2006; Panangala et al., 2006, Acharya et al., 2007; Maiti et al., 2008; Maiti et al., 2009; Castro et al., 2011; Wang et al., 2011; Yang et al., 2012). As a result, several researchers have reported the development of $E$. tarda-specific PCR assays with varying levels of success (Chen and Lai, 1998; Sakai et al., 2007; Lan et al., 2008; Sakai et al., 2009). The purpose of this study was to determine if $E$. tarda isolates from fish in the eastern United States demonstrate the same level of intraspecific variability seen in other geographic regions, in turn providing baseline information for the development of more reliable molecular diagnostic tools.

\section{Materials and methods}

\subsection{Isolation and identification of Edwardsiella tarda}

A total of 47 E. tarda isolates were obtained from the archived collections of the Thad Cochran National Warmwater Aquaculture Center (NWAC), The Aquaculture/Fisheries Center of the University of Arkansas-Pine Bluff, The Department of Biological Sciences at Auburn University, The Aquatic Microbiology Laboratory at Auburn University and the Louisiana Aquatic Diagnostic Laboratory (LADL). All isolates were collected from diseased fish. Briefly, cryostocks were streaked for isolation on Mueller-Hinton agar plates supplemented with 5\% sheep blood (Becton, Dickinson and Company, Sparks, MD) and grown overnight at $37^{\circ} \mathrm{C}$. Individual colonies were used for identification by the $\mathrm{BBL}^{\mathrm{TM}}$ Crystal $^{\mathrm{TM}}$ Enteric/Nonfermenter ID kit (BD, Franklin Lakes, NJ, USA) following the manufacturer's suggested protocol. Isolates were grouped by biotype based on their identification code and two representatives from each biotype were chosen for further analysis with the exception of biotype 20, which had only 1 representative. An ATCC E. tarda isolate (\#15947) as well as Edwardsiella ictaluri (S94711; S97-773; S07-698) isolates obtained from diseased channel catfish were included in the analysis.

\subsection{Conventional bacterial characterization}

For phenotypic analysis, cryostocks were streaked for isolation on Mueller-Hinton agar plates supplemented with 5\% sheep blood (Becton, Dickinson and Company, Sparks, MD) and grown overnight at $37^{\circ} \mathrm{C}\left(28^{\circ} \mathrm{C}\right.$ for $E$. ictaluri). An individual colony from each isolate was then subcultured onto Trypticase Soy Agar (TSA; Difco, St Louis, MO) for $48 \mathrm{~h}$ at $37^{\circ} \mathrm{C}$ and each isolate was then characterized by classical microbiological and biochemical tube tests and standardized procedures as described by MacFaddin (1981) and Lennette et al. (1985). All bacteriological media and supplies were prepared and sterilized according to manufacturer's recommendations. Based upon the results from individual tests, bacteria were classified according to referenced flow charts and identification schemes (Lennette et al., 1985; MacFaddin, 1981; Panangala et al., 2006).

\subsection{DNA extraction}

Individual colonies served to inoculate $5 \mathrm{ml}$ of Brain Heart Infusion (BHI) broth (Becton, Dickinson and Company, Sparks, MD) overnight at $37^{\circ} \mathrm{C}$ (E. tarda) or $28^{\circ} \mathrm{C}(E$. ictaluri) without shaking and cultures were pelleted by centrifugation. Genomic DNA from all isolates was extracted using the Puregene DNA Isolation Kit (Qiagen, Valencia, CA) following the manufacturer's suggested protocols for gram-negative bacteria and quantified spectrophotometrically (Nanodrop, Wilmington, DE, USA).

\subsection{Edwardsiella tarda specific $P C R$}

Genomic DNA from all isolates were analyzed using previously established protocols for PCR amplification of Edwardsiella spp., E. ictaluri, and E. tarda (Chen and Lai, 1998; Sakai et al., 2007; Lan et al., 2008; Sakai et al., 2009; Castro et al., 2011; Griffin et al., 2011) (Table 1). Briefly, the 25- $\mu$ l PCRs consisted of EconoTaq PLUS GREEN 2X Master Mix (Lucigen Corporation, Middleton, WI, USA); 20 pmol of each primer, $5 \mathrm{ng}$ of DNA template and nuclease-free $\mathrm{H}_{2} \mathrm{O}$ to volume. Amplification cycles used for denaturation, primer annealing and extension were carried out according to the respective protocol. Aliquots of each amplification reaction $(10 \mu \mathrm{l})$ were electrophoresed through a $1.25 \%$ (w/v) agarose gel, stained with ethidium bromide and visualized under ultraviolet light for the presence of the appropriate sized bands, determined by direct comparison with concurrently run DNA standards (Hyperladder II, Bioline USA inc., Taunton, MA, USA).

\subsection{Repetitive sequence mediated PCR (rep-PCR)}

Genetic fingerprinting for each isolate was carried out using modifications to existing protocols (Versalovic et al., 1991, 1994; Castro et al., 2011; Griffin et al., 2011) (Table 2). Three E. ictaluri isolates (S94-711; S97-773; S07698) and an Escherichia coli (ATCC\# 25952) were included in the analysis. Genomic DNA for these additional isolates was obtained as described above. Briefly, the analysis consisted of $25-\mu$ l reactions comprised of $13 \mu$ l of IQ Supermix (BioRad, Hercules, CA, USA), 20 (ERIC I and II) or 40 (BOX, ERIC II, GTG5) pmol of primer, $100 \mathrm{ng}$ of DNA template and nuclease-free $\mathrm{H}_{2} \mathrm{O}$ to volume. Amplifications were performed on a PTC 200 gradient cycler (MJ Research, 
Table 1

Primers used for Edwardsiella specific PCR.

\begin{tabular}{|c|c|c|c|}
\hline Target & Primer & Sequence $\left(5^{\prime}-3^{\prime}\right)$ & Reference \\
\hline E. tarda - & ChenF & CCTTATAAATTACTCGCT & \multirow[t]{2}{*}{ Chen and Lai, 1998} \\
\hline Hemolysin gene & ChenR & TTTGTGGAGTAACAGTTT & \\
\hline Edwardsiella tarda - & EtFimAF & CGGTAAAGTTGAGTTTACGGGTG & \multirow[t]{2}{*}{ Sakai et al., 2007} \\
\hline Major fimbrial subunit & EtFimAR & TGTAACCGTGTTGGCGTAAG & \\
\hline E. tarda - & EtFimDF & GGTAACCTGATTTGGCGTTC & \multirow[t]{2}{*}{ Sakai et al., 2007} \\
\hline Fimbrial subunit & EtFimDR & GGATCACCTGGATCTTATCC & \\
\hline E. tarda - & LanF & GCATGGAGACCTTCAGCAAT & \multirow[t]{2}{*}{ Lan et al., 2008} \\
\hline DNA gyrase subunit B & LanR & GCGGAGATTTTGCTCTTCTT & \\
\hline Typical E. tarda - & EttypF & TTCCGCAACCATGATCAAAG & \multirow[t]{2}{*}{ Sakai et al., 2009} \\
\hline Fimbrial gene cluster & EttypR & AGGGCATATATCCACTCACTG & \\
\hline Atypical E. tarda - & EtatypF & GAACAGCGCCTCTGTCTG & \multirow[t]{2}{*}{ Sakai et al., 2009} \\
\hline Fimbrial gene cluster & EtatypR & AATTGCTCTATACGCACGC & \\
\hline Edwardsiella sp. - & GenEDF & ACAGCCTGGAAGAGTCCTAC & \multirow[t]{2}{*}{ Sakai et al., 2009} \\
\hline Fimbrial gene cluster & GenEDR & TTGAGAGTCGCTGCTTAC & \\
\hline Edwardsiella ictaluri & Eict & ACTTATCGCCCTCGCAAC & \multirow[t]{2}{*}{ Griffin et al., 2011} \\
\hline Phosphoserine transaminase & Eict & GCCTCTGATAAGTGGTTCTCG & \\
\hline $16 S$ small-subunit ribosomal DNA & $27 \mathrm{~F}$ & GAGTTTGATCCTGGCTCAG & \multirow[t]{2}{*}{ Rainey et al., 1996} \\
\hline & $1525 \mathrm{R}$ & AGAAAGGAGGTGATCCAGCC & \\
\hline
\end{tabular}

Waltham, MA) with the following temperature profiles: 1 cycle at $95{ }^{\circ} \mathrm{C}$ for $10 \mathrm{~min}$; 5 cycles of $95^{\circ} \mathrm{C}$ for $1 \mathrm{~min}, 40^{\circ} \mathrm{C}$ for $1 \mathrm{~min}$, and $72{ }^{\circ} \mathrm{C}$ for $5 \mathrm{~min}$; 35 cycles of $95^{\circ} \mathrm{C}$ for $1 \mathrm{~min}$, $55^{\circ} \mathrm{C}$ for $1 \mathrm{~min}$, and $72{ }^{\circ} \mathrm{C}$ for $5 \mathrm{~min}$. Aliquots of each amplification reaction $(10 \mu \mathrm{l}$ each) were electrophoresed through a $1.5 \%(\mathrm{w} / \mathrm{v})$ agarose gel containing ethidium bromide $(1 \mu \mathrm{g} / \mathrm{ml})$ and visualized under ultraviolet light. Band sizes were assigned by direct comparison with concurrently run DNA standards (Hyperladder II, Bioline USA inc., Taunton, MA, USA).

\subsection{Multilocus DNA Sequencing}

A panel of 8 different housekeeping genes was selected for multilocus analysis (16S SSU, gyrA, gyrB, groEL, pgi, pgm, pho, rpoA). Primers were synthesized commercially (Sigma-Aldrich, The Woodlands, TX, USA) and with the exception of the universal prokaryotic 16S SSU rRNA primers (Rainey et al., 1996), all primers were designed specifically for this study (Table 3 ). To ensure amplification from all $E$. tarda isolates, targets were selected based on the presence of variable regions flanked by regions conserved between E. tarda and E. ictaluri. Primers were designed for amplification of $\sim 500-600 \mathrm{bp}$ fragments based on assembled genomes of E. tarda (GenBank \#CP001135; \#CP002154) and E. ictaluri (GenBank \#CP001600) (Wang et al., 2009; van Soest et al., 2011; Williams et al., 2012).

Table 2

Primers used for repetitive sequence mediated PCR.

\begin{tabular}{lll}
\hline Primer & Sequence $\left(5^{\prime}-3^{\prime}\right)$ & Reference \\
\hline BOX & CTACGGCAAGGCGACGCTGAC G & Versalovic et al., 1994 \\
ERIC I & ATGTAAGCTCCTGGGGATTCAC & Versalovic et al., 1991 \\
ERIC II & AAGTAAGTGACTGGGGTGAGCG & Versalovic et al., 1991 \\
GTG $_{5}$ & GTGGTGGTGGTGGTG & Versalovic et al., 1994 \\
\hline
\end{tabular}

Amplification reactions ( $25 \mu \mathrm{l}$ ) were performed using $13 \mu \mathrm{l}$ of iProof $^{\mathrm{TM}}$ High-fidelity Mastermix (BioRad, Hercules, CA), 20 pmol of each primer, $10 \mathrm{ng}$ of genomic DNA and nuclease-free water to volume using the following thermocycling profile: $3 \mathrm{~min}$ denaturation at $98^{\circ} \mathrm{C} ; 45$ cycles of $30 \mathrm{~s}$ at $98{ }^{\circ} \mathrm{C}, 30 \mathrm{~s}$ at $55^{\circ} \mathrm{C}, 2 \mathrm{~min}$ at $72{ }^{\circ} \mathrm{C}$; and 7 min extension at $72^{\circ} \mathrm{C}$. Amplicons were visualized with UV light after electrophoretic migration through a $1.25 \%$ agarose gel containing ethidium bromide $(1 \mu \mathrm{g} / \mathrm{ml})$ and were either gel-excised or purified directly using Qiagen Qiaquick $^{\mathrm{TM}}$ columns (Qiagen, Valencia, CA). The purified products were either directly sequenced using the corresponding primers or cloned into a plasmid vector (pCR ${ }^{\circledR}$ 4Blunt-TOPO ${ }^{\circledR}$; Zero Blunt ${ }^{\circledR}$ TOPO ${ }^{\circledR}$ PCR Cloning Kit for sequencing, Invitrogen, San Diego, CA) and sequenced according to the manufacturer's instructions. Purified PCR products or plasmid DNA was cycle-sequenced from both strands using ABI BigDye ${ }^{\mathrm{TM}}$ chemistry (Applied Biosystems, Foster City, CA), alcohol-precipitated and run on an ABI Prism $3730^{\mathrm{TM}}$ automated sequencer (Applied Biosystems, Foster City, CA). Reaction components and thermal cycling conditions were the same for all primers sets Contiguous sequences were assembled using the corresponding chromatograms and the SeqMan ${ }^{\mathrm{TM}}$ utility of the Lasergene software package (DNAStar, Madison, WI).

\subsection{Phylogenetic analysis}

Genetic fingerprints generated by rep-PCR were analyzed using the Quantity One software v. 4.6.5 (Bio-Rad Laboratories Inc., Hercules, CA) to calculate the Dice coefficients and generate a dendrogram based on unweighted pair-group method using arithmetic averages (UPGAMA).

Sequence fragments generated from multilocus sequencing of several housekeeping genes were aligned using the Clustal W application of MEGA version 5.0 (Tamura et al., 2011). For each gene, reference sequences 
Table 3

Sequencing primers used for genetic identification. All primer sequences were designed specifically for this study unless otherwise noted*.

\begin{tabular}{|c|c|c|}
\hline Target & Primer & Sequence $\left(5^{\prime}-3^{\prime}\right)$ \\
\hline Glucose-6-phosphate isomerase & $\begin{array}{l}\text { PgiF } \\
\text { PgiR }\end{array}$ & $\begin{array}{l}\text { TGCCGACCGTTTCTCTAAGT } \\
\text { GACCCAGTCCCAGAACTCAA }\end{array}$ \\
\hline Phosphoglucomutase & $\begin{array}{l}\operatorname{PgmF} \\
\operatorname{PgmR}\end{array}$ & $\begin{array}{l}\text { TCGCCATTCTGACCCATAAC } \\
\text { GCTGGAGACCAGCGTCTTAC }\end{array}$ \\
\hline DNA-directed RNA polymerase $\alpha$-subunit & $\begin{array}{l}\text { RpoAF } \\
\text { RpoAR }\end{array}$ & $\begin{array}{l}\text { CGGTACGCTGTACCAGATCA } \\
\text { CCGAGGTTGAGATTGATGGT }\end{array}$ \\
\hline Phosphate transport system regulatory protein & $\begin{array}{l}\text { PhoF } \\
\text { PhoR }\end{array}$ & $\begin{array}{l}\text { ATATCCGCACCCAGGTAATG } \\
\text { TGTCAGCAGCTGTTCCAGAT }\end{array}$ \\
\hline Chaperonin GroEl & $\begin{array}{l}\text { GroeLF } \\
\text { GroeLR }\end{array}$ & $\begin{array}{l}\text { GTTCATTCTGCTGGCTGACA } \\
\text { GCTCTTCGTTGATGCCTTTC }\end{array}$ \\
\hline DNA gyrase subunit $A$ & $\begin{array}{l}\text { GyrAF } \\
\text { GyrAR }\end{array}$ & $\begin{array}{l}\text { AGCGCCTTGTACTCATCCAG } \\
\text { TGGTGCATGAGATCCCCTAT }\end{array}$ \\
\hline DNA gyrase subunit B & $\begin{array}{l}\text { GyrBF } \\
\text { GyrBR }\end{array}$ & $\begin{array}{l}\text { CCCTGTCTGAAAAGCTGGAG } \\
\text { CTCGTTCATCAGCGACTCAA }\end{array}$ \\
\hline 16S small subunit ribosomal DNA & $\begin{array}{l}27 F \\
1525 R \\
16 S R 2 \\
16 S R 3 \\
16 S R 4 \\
16 S R 5\end{array}$ & $\begin{array}{l}\text { GAGTTTGATCCTGGCTCAG }^{\mathrm{a}} \\
\text { AGAAAGGAGGTGATCCAGCC }^{\mathrm{a}} \\
\text { CTTCTTTTGCAACCCACTCC } \\
\text { CCCAACATTTCACAACACGA } \\
\text { TACGCATTTCACCGCTACAC } \\
\text { GTGCAATATTCCCCACTGCT }\end{array}$ \\
\hline
\end{tabular}

a Rainey et al. (1996).

from the published genomes of E. tarda (GenBank \#CP001135; \#CP002154) and E. ictaluri (GenBank \#CP001600) were included in the analysis. Corresponding gene sequences from another member of the Enterobacteriaceae, Klebsiella pneumoniae (GenBank \#CP000964), were included as outliers. Phylogenetic trees were constructed in MEGA with the neighbor-joining algorithm (Saitou and Nei, 1987), using the Kimura 2-parameter model (Kimura, 1980). Bootstrap support was calculated from 500 repetitions (Felsentein, 1985).

\subsection{Estimation of $G+C$ content}

The genomic $\mathrm{G}+\mathrm{C}$ content was estimated by a fluorometric method measuring thermal denaturation of DNA (Gonzalez \& Saiz-Jiminez, 2002) and was performed on a CFX96 ${ }^{\text {TM }}$ Real-time PCR Detection System (BioRad, Hercules, CA) and the accompanying software. Briefly, 50$\mu \mathrm{l}$ reactions consisted of $1 \mu \mathrm{l}$ of SsoFast ${ }^{\mathrm{TM}}$ EvaGreen $^{\circledR}$ Supermix (BioRad, Hercules, CA), $5 \mu$ l of $0.5 \mathrm{X}$ salinesodium citrate buffer ( $\mathrm{pH}$ 7.0), $5 \mu \mathrm{g}$ of genomic DNA and nuclease-free water to volume. Thermal conditions consisted of a ramp from $25^{\circ} \mathrm{C}$ to $100^{\circ} \mathrm{C}$ at $1^{\circ} \mathrm{C} \mathrm{min}{ }^{-1}$, with fluorescence measurements performed at each step in the ramp. Each isolate was analyzed in triplicate.

\subsection{Carbon source utilization}

Metabolic fingerprints were determined using Biolog's Microlog Microbial Identification system (GEN II MicroStation System; Biolog, Hayward, CA, USA) according to the manufacturer's suggested protocol. Briefly, after culturing each isolate under the above-mentioned conditions, bacterial suspensions were prepared by removing bacterial colonies from the plate surface with a sterile cotton swab and agitating it in $20 \mathrm{~mL}$ of Biolog's GN/GP-IF supplemented with sodium thioglycolate. The bacterial suspension was adjusted to $61 \%$ transmittance at $590 \mathrm{~nm}$ with a spectrophotometer. A $150 \mu \mathrm{L}$ aliquot of this suspension was dispensed into each well of a Biolog GN2 microplate. The plates were incubated for $24 \mathrm{~h}$ at $35^{\circ} \mathrm{C}\left(28^{\circ} \mathrm{C}\right.$ for E. ictaluri) and analyzed using the MicroLog 3 v 4.20 .05 software providing species-level identification (similarity index $>0.50$ ).

\subsection{Antimicrobial susceptibility}

The minimal inhibitory concentration (MIC) of 17 different antimicrobial agents to the $17 \mathrm{E}$. tarda isolates from fish and a quality control ( $E$. coli) were tested using the Sensititre 18-24 h MIC and breakpoint susceptibility plates and JustOne strips (Trek Diagnostic System, West Sussex, UK), containing two fold dilutions of florfenicol (0.12$128 \mu \mathrm{g} / \mathrm{ml}$ ), and the GN2F-SENSITITRE GRAM NEGATIVE PLATE FORMAT (Trek Diagnostic System, West Sussex, UK), containing two fold dilutions of: Amikacin $(8-64 \mu \mathrm{g} / \mathrm{ml})$, Ampicillin $(4-32 \mu \mathrm{g} / \mathrm{ml})$, Ampicillin/sulbactam 2:1 ratio $(4 / 2-32 / 16 \mu \mathrm{g} / \mathrm{ml})$, Aztreonam $(8-32 \mu \mathrm{g} / \mathrm{ml})$, Cefazolin (4$32 \mu \mathrm{g} / \mathrm{ml})$, Cefepime ( $4-32 \mu \mathrm{g} / \mathrm{ml})$, Cefotetan $\mathrm{Na}(8-32 \mu \mathrm{g} /$ $\mathrm{ml})$, Ceftriaxone $(1-64 \mu \mathrm{g} / \mathrm{ml})$, Ceftazidime $(1-32 \mu \mathrm{g} / \mathrm{ml})$, Cefoxitin $(4-32 \mu \mathrm{g} / \mathrm{ml})$, Cefuroxime $(4-32 \mu \mathrm{g} / \mathrm{ml})$, Ciprofloxacine $(0.5-4 \mu \mathrm{g} / \mathrm{ml})$, Imipenem $(2-16 \mu \mathrm{g} / \mathrm{ml})$ Gatifloxacin $(1-8 \mu \mathrm{g} / \mathrm{ml})$, Meropenem $(1-8 \mu \mathrm{g} / \mathrm{ml})$, Piperacillin (16-128 $\mu \mathrm{g} / \mathrm{ml})$, Nitrofurantoin (16-128 $\mu \mathrm{g} / \mathrm{ml})$, Piperacillin/tazobactam constant $4(16 / 4-128 / 4 \mu \mathrm{g} / \mathrm{ml})$, Ticarcillin/ clavulanic acid constant $2(16 / 2-64 / 2 \mu \mathrm{g} / \mathrm{ml})$, Cefpodoxime $(2-16 \mu \mathrm{g} / \mathrm{ml})$, Tobramycin $(4-8 \mu \mathrm{g} / \mathrm{ml})$, Gentamicin (8$0.5 \mu \mathrm{g} / \mathrm{ml})$, Trimethoprim/sulfamethoxazole (2/38-0.5/ $9.5 \mu \mathrm{g} / \mathrm{ml}$ ), using the manufacturer's suggested protocol. Briefly, the E. tarda isolates, along with a reference $E$. coli isolate (ATCC 25922) quality control were plated on Mueller-Hinton agar plates supplemented with 5\% sheep 


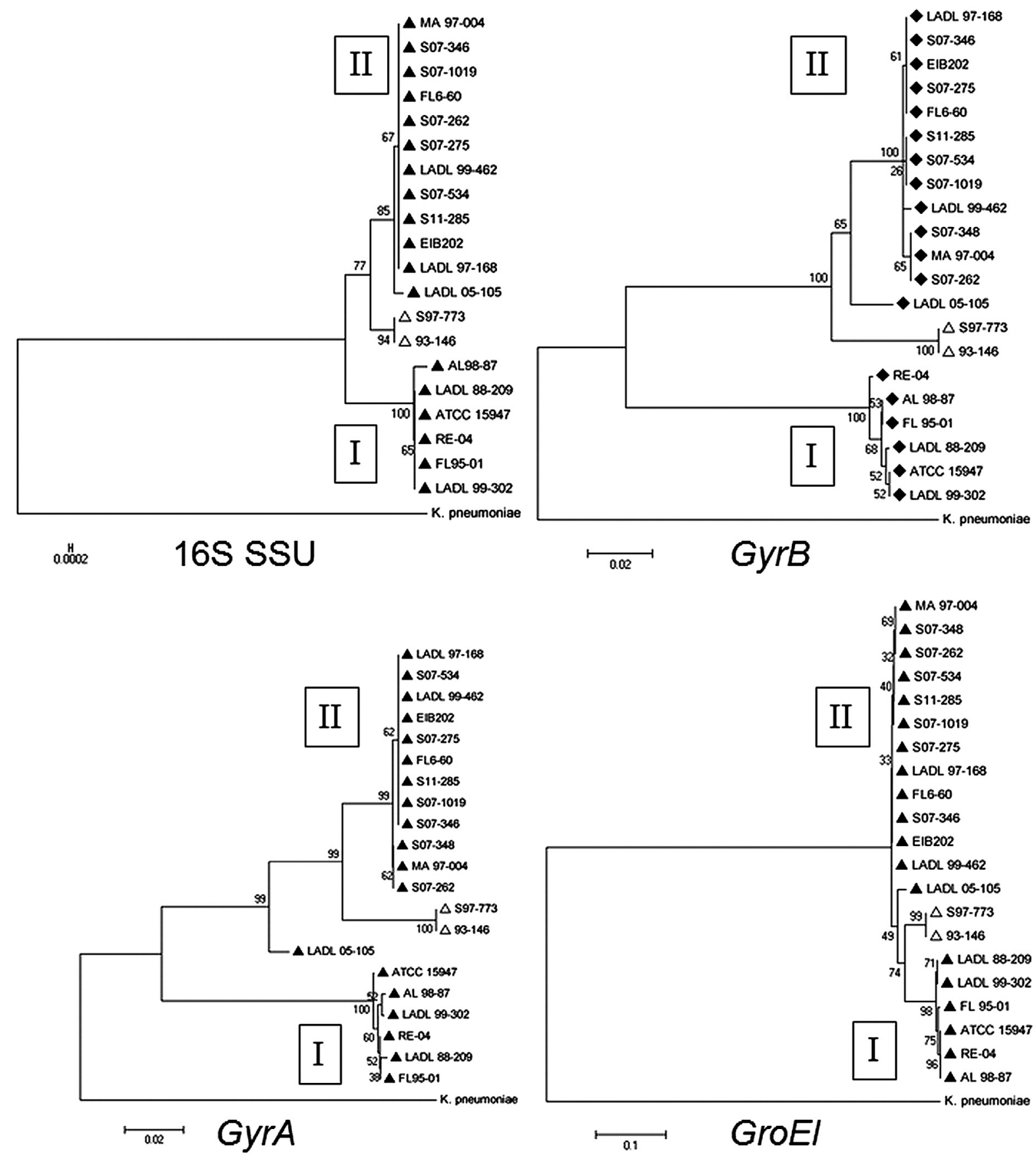

Fig. 1. Phylogenetic analysis of Edwardsiella tarda (black triangle) and Edwardsiella ictaluri (white triangle) gene sequences identifying two distinct genetic groups (I and II). Reference sequences for E. tarda (FL6-60; GenBank \#CP002154; EIB202; GenBank \#CP001135) and E. ictaluri (93-146; GenBank \#CP001600) are included. Units are the number of base substitutions per site. Klebsiella pneumoniae (GenBank \#CP000964) was chosen as an out-group. Bootstrap values are located at the nodes.

serum (Becton, Dickinson and Company, Sparks, MD) and grown overnight at $37^{\circ} \mathrm{C}$ and incubated for $24 \mathrm{~h}$, at $27^{\circ} \mathrm{C}$. Inocula were prepared by suspending colonies in $1 \mathrm{XPBS}$ to a $0.5 \mathrm{McFarland}$ standard. This suspension was diluted 1000fold in Mueller-Hinton broth and $50 \mu \mathrm{l}$ were added to each well of the sensititre plates containing the different antibiotics. For each plate, three wells contained the bacterial inoculum without an antibacterial agent (positive control) and one well contained the bacterial inoculum with an antibacterial agent to prevent bacterial growth (negative control). Tested plates were covered with an adhesive seal, provided by the manufacturer, and incubated for $24 \mathrm{~h}$ at $27^{\circ} \mathrm{C}$. Bacterial growth was checked visually after removing the adhesive seal at $24 \mathrm{~h}$ post inoculation. The MIC value was defined as the lowest concentration exhibiting no visible growth. 

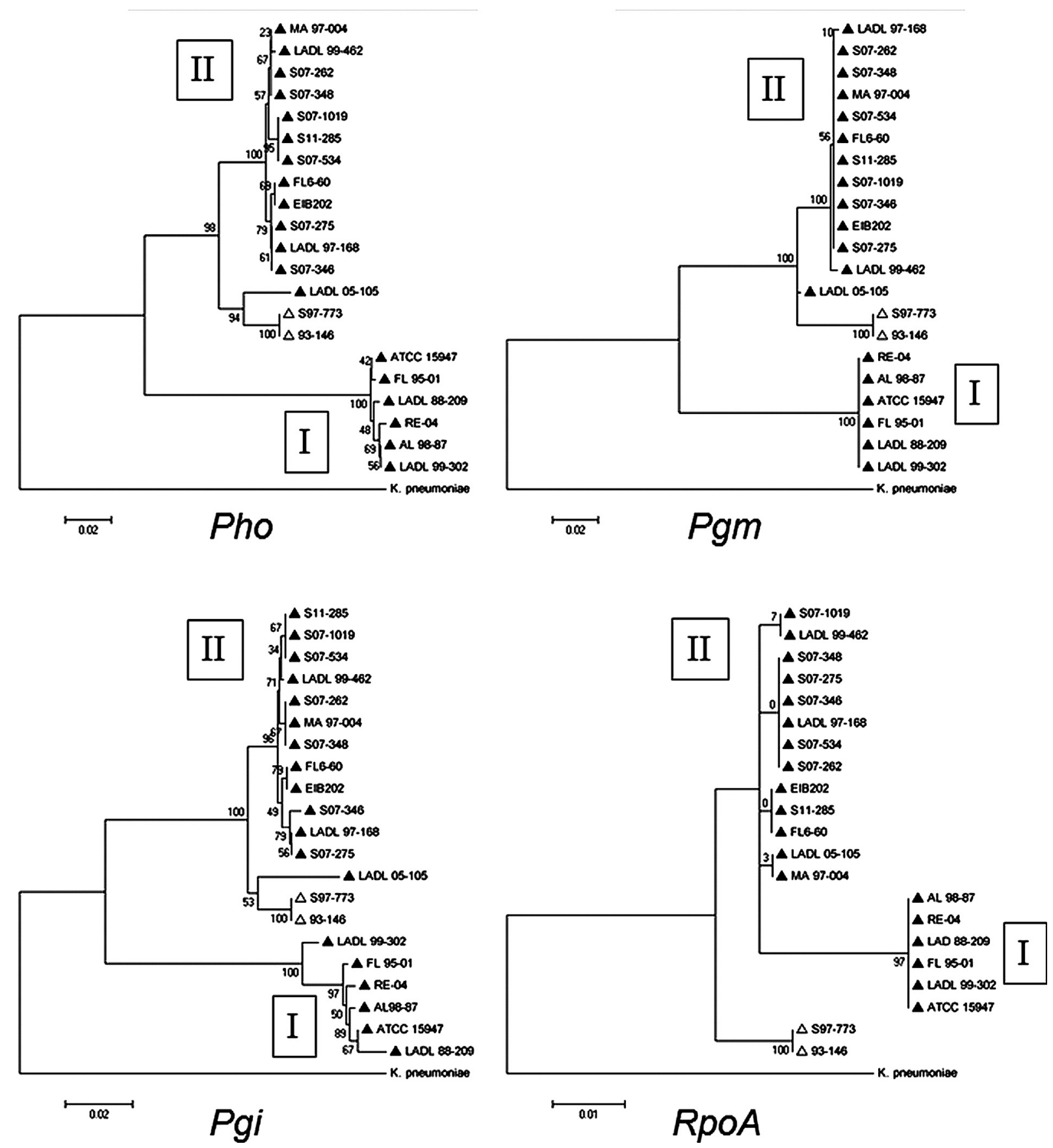

Fig. 2. Phylogenetic analysis of Edwardsiella tarda (black triangle) and Edwardsiella ictaluri (white triangle) gene sequences identifying 2 distinct genetic groups (I and II). Reference sequences for E. tarda (FL6-60; GenBank \#CP002154; EIB202; GenBank \#CP001135) and E. ictaluri (93-146; GenBank \#СР001600) are included. Units are the number of base substitutions per site. Klebsiella pneumoniae (GenBank \#CP000964) was chosen as an out-group. Bootstrap values are located at the nodes.

\subsection{Fatty Acid Methyl Ester analysis}

Gas chromatographic analysis of cellular fatty acids (GC-FAME) was performed by Microbial Identification, Inc (MIDI, Newark, DE). Species level identification and confidence levels were determined using the Sherlock $^{\mathbb{R}}$ Microbial Identification System (Sasser, 1990).

\section{Results}

\subsection{Genetic sequencing and phylogenetic analysis}

Multi-locus sequencing identified two distinct genotypes of $E$. tarda (DNA group I; DNA group II). Regardless of gene target, the $E$. tarda isolates formed 2 distinct clusters with high bootstrap support (Figs. 1 and 2). Five of the $E$. 
Table 4

Sequence similarity (\%) of Edwardsiella tarda and Edwardsiella ictaluri isolates used in this study to E. tarda FL6-60 (GenBank \#CP002154) and E. ictaluri 93146 (GenBank \#CP001600) assembled genomes.

\begin{tabular}{|c|c|c|c|c|c|c|c|c|c|c|c|c|c|c|c|c|}
\hline \multirow[t]{2}{*}{ Isolate } & \multicolumn{8}{|c|}{ Edwardsiella tarda } & \multicolumn{8}{|c|}{ Edwardsiella ictaluri } \\
\hline & $16 S$ & gyrB & gyrA & groEL & pho & pgi & pgm & гроA & $16 S$ & gyrB & gyrA & groEL & pho & pgi & pgm & гроА \\
\hline \multicolumn{17}{|l|}{ DNA Group I } \\
\hline ATCC 15947 & 99.3 & 85.6 & 86.4 & 93.8 & 88.5 & 85.9 & 86.8 & 97.8 & 99.3 & 84.6 & 85.0 & 92.5 & 88.5 & 85.9 & 85.5 & 96.9 \\
\hline RE-04 & 99.3 & 86.0 & 86.2 & 93.8 & 88.5 & 85.5 & 86.8 & 97.8 & 99.3 & 85.0 & 85.2 & 92.5 & 88.5 & 85.5 & 85.5 & 96.9 \\
\hline AL98-87 & 99.2 & 85.8 & 86.0 & 93.8 & 88.5 & 85.7 & 86.6 & 97.8 & 99.2 & 85.2 & 85.4 & 92.5 & 88.5 & 85.7 & 85.3 & 96.9 \\
\hline LADL 88-209 & 99.3 & 85.6 & 86.0 & 94.0 & 87.7 & 85.7 & 86.8 & 97.8 & 99.3 & 84.8 & 85.0 & 93.1 & 87.7 & 85.4 & 85.5 & 96.9 \\
\hline FL95-01 & 99.3 & 85.8 & 86.2 & 93.8 & 88.5 & 85.7 & 86.6 & 97.8 & 99.3 & 84.6 & 85.2 & 92.9 & 88.5 & 85.7 & 85.3 & 96.9 \\
\hline LADL 99-302 & 99.3 & 85.6 & 86.0 & 94.0 & 88.5 & 85.6 & 86.6 & 97.8 & 99.3 & 84.6 & 85.4 & 93.1 & 88.5 & 85.6 & 85.3 & 96.9 \\
\hline \multicolumn{17}{|l|}{ DNA Group II } \\
\hline MA $97-004^{\mathrm{a}}$ & 100 & 99.6 & 99.8 & 99.6 & 99.4 & 99.5 & 100 & 100 & 99.7 & 94.9 & 95.0 & 94.8 & 97.7 & 95.5 & 95.5 & 98.4 \\
\hline $\mathrm{S} 11-285^{\mathrm{a}}$ & 100 & 99.8 & 100 & 99.8 & 99.4 & 98.9 & 100 & 100 & 99.7 & 94.7 & 95.2 & 95.0 & 97.7 & 95.3 & 95.5 & 98.4 \\
\hline LADL $97-168^{a}$ & 100 & 100 & 100 & 100 & 99.6 & 99.8 & 100 & 100 & 99.7 & 94.5 & 95.2 & 95.1 & 97.5 & 95.5 & 95.5 & 98.4 \\
\hline LADL $99-462^{\mathrm{a}}$ & 100 & 99.6 & 100 & 99.6 & 99.6 & 99.3 & 99.6 & 100 & 99.7 & 94.5 & 95.2 & 95.1 & 97.8 & 95.3 & 95.0 & 98.4 \\
\hline S07-346 & 100 & 100 & 100 & 100 & 99.4 & 99.8 & 100 & 100 & 99.7 & 94.5 & 95.2 & 95.1 & 97.3 & 95.5 & 95.5 & 98.4 \\
\hline S07-262 ${ }^{\mathrm{a}}$ & 100 & 99.6 & 99.8 & 99.6 & 99.4 & 99.5 & 100 & 100 & 99.7 & 94.9 & 95.0 & 94.8 & 97.7 & 95.5 & 95.5 & 98.4 \\
\hline S07-534 & 100 & 99.8 & 100 & 99.8 & 99.4 & 98.9 & 100 & 100 & 99.7 & 94.7 & 95.2 & 95.0 & 97.7 & 95.3 & 95.4 & 98.4 \\
\hline S07-275 & 100 & 100 & 100 & 100 & 99.6 & 99.6 & 100 & 100 & 99.7 & 94.5 & 95.2 & 95.1 & 97.5 & 95.3 & 95.5 & 98.4 \\
\hline S07-1019 & 100 & 99.8 & 100 & 99.8 & 98.8 & 98.7 & 100 & 100 & 99.7 & 94.7 & 95.2 & 95.0 & 97.5 & 95.1 & 95.5 & 98.4 \\
\hline S07-348 & 100 & 99.6 & 99.8 & 99.6 & 99.4 & 99.5 & 100 & 100 & 99.7 & 94.9 & 95.0 & 94.8 & 97.7 & 95.5 & 95.5 & 98.4 \\
\hline LADL $05-105^{\mathrm{b}}$ & 99.9 & 97.0 & 95.2 & 97.9 & 96.1 & 94.6 & 98.3 & 100 & 99.8 & 95.4 & 94.4 & 95.1 & 96.7 & 96.6 & 96.3 & 98.4 \\
\hline \multicolumn{17}{|c|}{ Edwardsiella ictaluri } \\
\hline S97-773 & 99.7 & 94.5 & 95.2 & 95.1 & 97.5 & 95.7 & 95.5 & 98.4 & 100 & 100 & 100 & 100 & 100 & 100 & 100 & 100 \\
\hline
\end{tabular}

a Typical Edwardsiella tarda as defined by Sakai et al. (2009)

b Atypical Edwardsiella tarda as defined by Sakai et al. (2009)

tarda isolates (AL 98-87; FL 95-01; LADL 88-209; LADL 99302; RE-04) clustered with the ATCC reference strain (DNA group I). The remainder of the isolates grouped with the reference $E$. tarda genomes (DNA group II), clustering with E. ictaluri to form a clade sister to DNA group I. One genetic variant, LADL 05-105, clustered with DNA group II but diverged from the remainder of the isolates. Regardless of genetic group (I or II), all E. tarda isolates demonstrated greater than $98 \%$ similarity to E. tarda $16 \mathrm{~S}$ SSU, GyrB, Pgm, and Pho sequences available in GenBank, although each group demonstrated similarities to different entries. For all genes, all isolates from DNA group II were more than $99 \%$

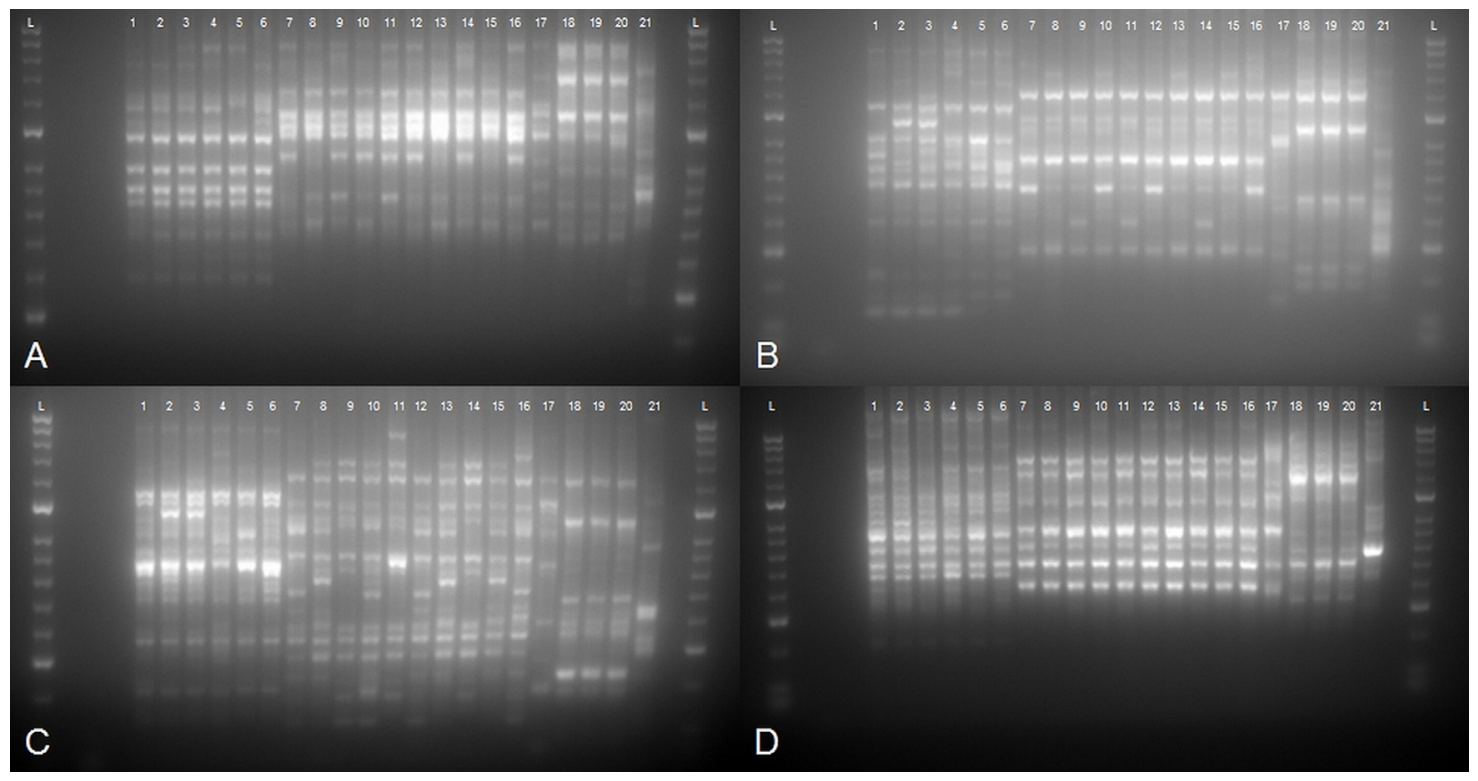

Fig. 3. Repetitive sequence mediated PCR amplification of DNA from Edwardsiella tarda (lanes 1-17), Edwardsiella ictaluri (Lanes 18-20) and Escherichia coli (lane 21). Genetic profiles were generated using GTG $_{5}$ (A), ERIC II (B), ERIC I and II (C) and BOX (D) primers. Lane designations are as follows for all gels: L = Hyperladder II; lanes 1 ATCC 15947; 2 = RE-04; 3 = AL98-87; 4 = LADL 88-209; 5 = FL95-01; 6 = LADL 99-302; 7 = MA 97-004; 8 = S11-285; 9 = LADL 97$168 ; 10=$ LADL 99-462; 11 = S07-346; 12 = S07-262; 13 = S07-534; 14 = S07-275; 15 = S07-1019; 16 = S07-348; 17 = LADL 05-105; 18 = S94-711; 19= S97$773 ; 20=$ S07-698; 21 = ATCC 25922 . 


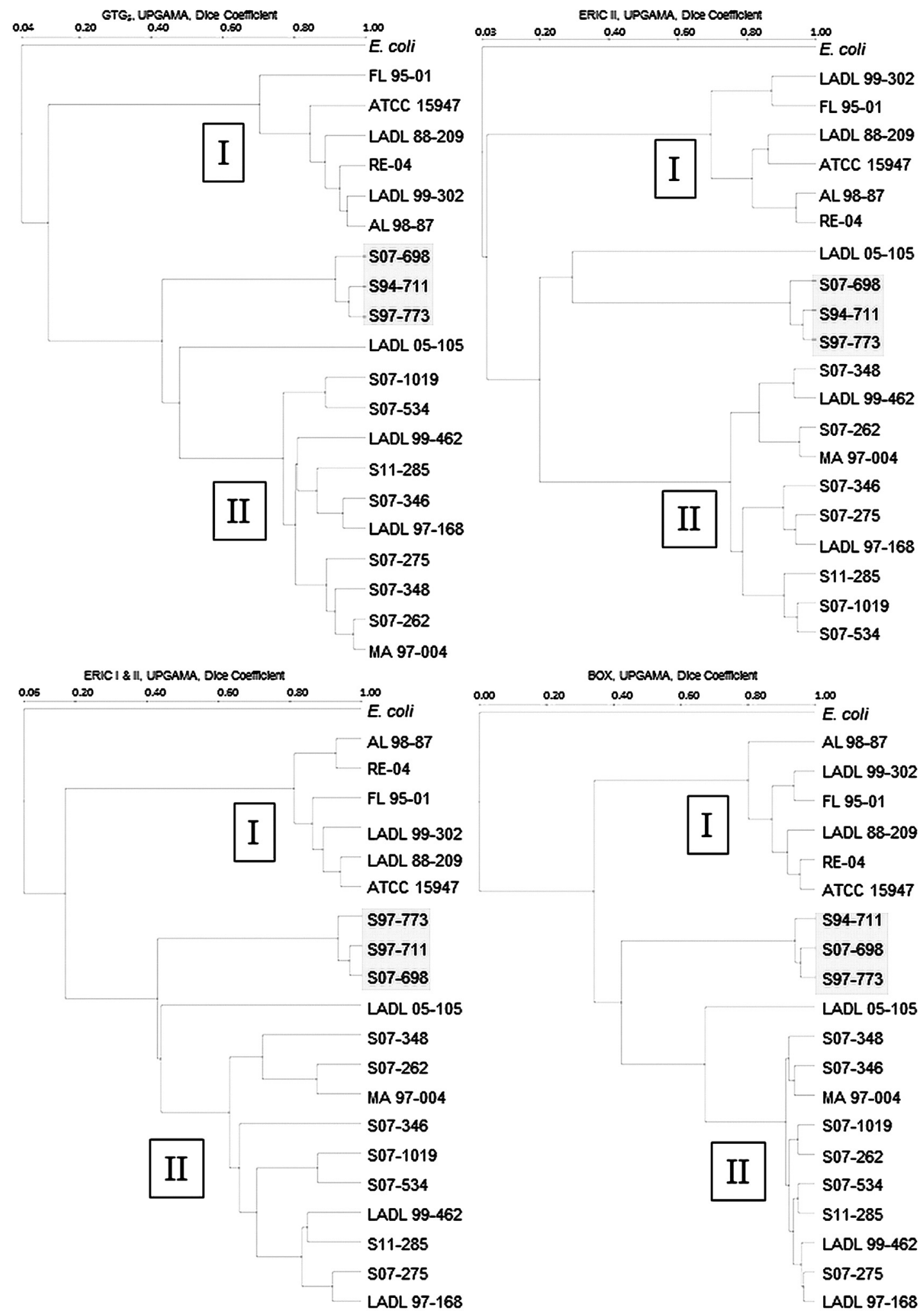

Fig. 4. UPGAMA dendograms based on Dice coefficient matrices generated from PCR amplification of Edwardsiella tarda DNA using four different primer sets. The isolates consistently formed two distinct clusters (I and II). Three E. ictaluri (S94-711; S97-773; S07-696; gray highlight) isolates were also included in the analysis. 


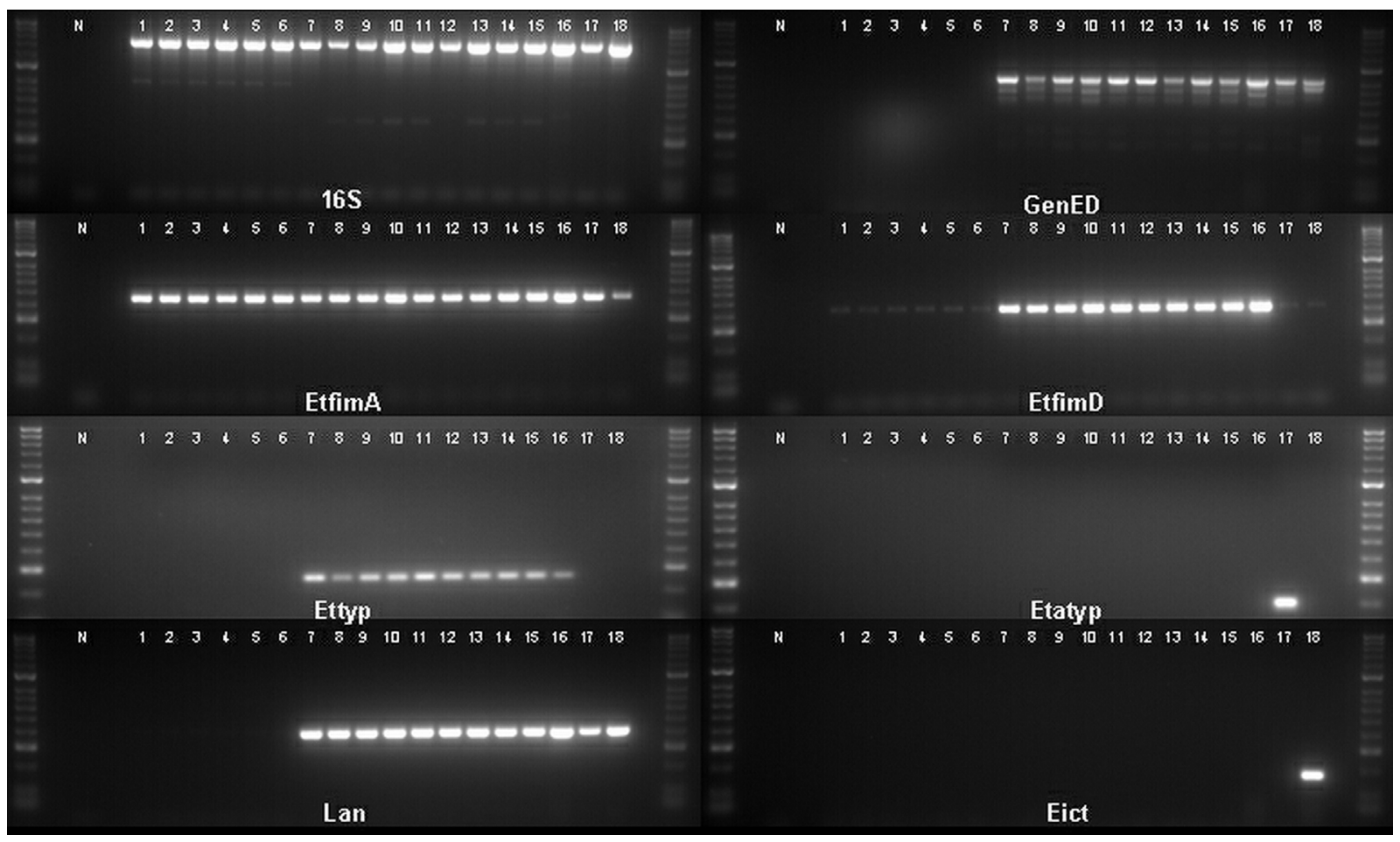

Fig. 5. Polymerase chain reaction amplification of bacterial isolates identified biochemically and by $16 \mathrm{~S}$ sequencing as Edwardsiella tarda (lanes 1-17) or Edwardsiella ictaluri (lane 18). Primer sequences and corresponding publications can be found in Table 1 . Lane designations are as follows for all gels: $\mathrm{N}=$ no template control; 1 = ATCC 15947; 2 = RE-04; 3 = AL98-87; 4 = LADL 88-209; 5 = FL95-01; 6 = LADL 99-302; 7 = MA 97-004; 8 = S11-285; 9 = LADL 97-168; $10=$ LADL 99-462; 11 = S07-346; 12 = S07-262; 13 =S07-534; 14 =S07-275; $15=$ S07-1019; 16 = S07-348; 17 = LADL 05-105; $18=$ S97-773 (Edwardsiella ictaluri).

similar to the published $E$. tarda genomes, with the exception of LADL 05-105, which demonstrated slightly more variability (94-100\%). Alternatively, DNA group I, which includes the ATCC reference strain, demonstrated remarkable differences from these genomes for all targets (Table 4). For all gene targets, DNA group II, including LADL 05-105, demonstrated mofre similarity to E. ictaluri than to DNA group I. Sequences for all targets for all isolates have been deposited in GenBank (\#JX866952-JX867095).

\subsection{Repetitive sequence mediated PCR}

Genetic profiles for the isolates used in this study were consistent with the multi-locus sequencing data, regardless of primer set. The isolates formed two distinct clusters (Figs. 3 and 4), with LADL 05-105 again falling sister to DNA group II. The two predominant E. tarda clusters demonstrated no greater than $40 \%$ similarity between them, regardless of primer set. All isolates, consistently fell into the same clusters, with 5 of the isolates (AL 98-87; FL 9501; LADL 88-209; LADL 99-302; RE-04) grouping with the ATCC reference strain, and the remaining isolates grouping more closely to E. ictaluri (Fig. 4).

\subsection{Edwarsiella tarda-specific PCR}

Results for Edwardsiella-specific PCRs from $5 \mathrm{ng}$ of template DNA were variable (Fig. 5). All isolates were positive by $16 \mathrm{~S}$ rDNA PCR. Positive reactions were also observed for DNA group I from the E. tarda fimbrial subunit primers (EtfimD; Sakai et al., 2007), with faint bands observed for the E. tarda major fimbrial subunit primers (EtfimA; Sakai et al., 2007). There was no amplification from DNA group I isolates with any other primer sets. In contrast, strong positive reactions were observed for isolates from DNA group II for the Edwardsiella fimbrial gene cluster (GenEd; Sakai et al., 2009), the E. tarda fimbrial subunit (EtfimD), and E. tarda DNA gyrase subunit B (EtgyrB; Lan et al., 2008). All group II isolates were positive for the E. tarda major fimbrial subunit (EtfimA) and the typical E. tarda fimbrial gene cluster (Ettyp; Sakai et al., 2009), with the exception of LADL 05-105, which had only a faint positive for the $E$. tarda major fimbrial subunit (EtfimA) and was negative for the typical E. tarda fimbrial gene cluster (Ettyp). However, LADL 05-105 was positive for the atypical E. tarda fimbrial gene cluster (Etatyp; Sakai et al., 2009). By comparison, positive reactions were observed for $E$. ictaluri isolate S97-773 from the Edwardsiella fimbrial gene cluster (GenEd), the Edwardsiella fimbrial subunit, E. tarda DNA gyrase subunit B and E. ictaluri specific primers, with a faint positive for the E. tarda major fimbrial subunit. No positive reactions were observed for any E. tarda isolates from E. ictaluri specific primers or primers amplifying the E. tarda hemolysin gene (Chen and Lai, 1998). 
Table 5

Fluorometric estimation of $\mathrm{G}+\mathrm{C}$ content (\%) based on genomic DNA melting temperatures $\left(T_{\mathrm{m}}\right)$. $\mathrm{G}+\mathrm{C}$ content $(\%)$ was estimated by the mean $T_{\mathrm{m}}\left({ }^{\circ} \mathrm{C}\right)$ from triplicate reactions.

\begin{tabular}{|c|c|c|}
\hline Isolate & $\mathrm{G}+\mathrm{C}$ content $(\%)$ & $T_{\mathrm{m}}( \pm$ S.D. $)$ \\
\hline \multicolumn{3}{|l|}{ DNA Group I } \\
\hline ATCC 15947 & 56.0 & $82.3( \pm 0.2)$ \\
\hline RE-04 & 55.7 & $82.1( \pm 0.3)$ \\
\hline AL98-87 & 57.2 & $82.9( \pm 0.2)$ \\
\hline LADL 88-209 & 56.6 & $82.6( \pm 0.0)$ \\
\hline FL95-01 & 56.5 & $82.5( \pm 0.1)$ \\
\hline LADL 99-302 & 56.1 & $82.3( \pm 0.1)$ \\
\hline Group mean & 56.4 & $82.5( \pm 0.3)$ \\
\hline \multicolumn{3}{|l|}{ DNA Group II } \\
\hline MA 97-004 & 59.9 & $84.3( \pm 0.1)$ \\
\hline S11-285 & 60.5 & $84.5( \pm 0.4)$ \\
\hline LADL 97-168 & 58.9 & $83.7( \pm 0.1)$ \\
\hline LADL 99-462 & 60.3 & $84.5( \pm 0.2)$ \\
\hline S07-346 & 60.6 & $84.6( \pm 0.0)$ \\
\hline S07-262 & 60.7 & $84.7( \pm 0.1)$ \\
\hline S07-534 & 60.3 & $84.5( \pm 0.4)$ \\
\hline S07-275 & 60.6 & $84.6( \pm 0.4)$ \\
\hline S07-1019 & 60.5 & $84.5( \pm 0.1)$ \\
\hline S07-348 & 60.5 & $84.5( \pm 0.1)$ \\
\hline LADL 05-105 & 60.3 & $84.5( \pm 0.1)$ \\
\hline Group mean & 60.3 & $84.5( \pm 0.3)$ \\
\hline \multicolumn{3}{|c|}{ Edwardsiella ictaluri } \\
\hline S97-773 & 58.4 & $83.5( \pm 0.2)$ \\
\hline
\end{tabular}

\subsection{Estimation of $G+C$ content}

All isolates from DNA group I, which includes the ATCC type strain (\#15947) demonstrated lower melting temperatures than DNA group II and E. ictaluri. The average melting temperature for DNA group I was $82.3^{\circ} \mathrm{C}$ compared to $84.5^{\circ} \mathrm{C}$ for DNA group II. Isolate LADL 05-105, a genetic variant of DNA group II, demonstrated a melting temperature of $84.5^{\circ} \mathrm{C}$, while S97-773, the E. ictaluri isolate melted at $83.5^{\circ} \mathrm{C}$. Using the relationship between fluorometric estimations of genomic melting temperatures and $\mathrm{G}+\mathrm{C}$ content (Gonzalez and Saiz-Jimenez, 2002), the mean $G+C$ content for DNA group I was $56.4 \%, 60.2 \%$ for DNA group II, and $58.4 \%$ for E. ictaluri. Results of this analysis are tabulated in Table 5 .

Table 6

Biochemical identification of Edwardsiella isolates used in this study; $\mathrm{CL}=$ confidence level; Sim = similarity index.

\begin{tabular}{|c|c|c|c|c|}
\hline Isolate & Host (State) & BBL Crystal ID & BBL Crystal Code ${ }^{a, b}$ & Biolog ID; (CL; Sim) \\
\hline \multicolumn{5}{|l|}{ DNA Group I } \\
\hline ATCC 15947 & Human (KY) & Edwardsiella tarda & $2002010013^{\mathrm{a}}$ & E. tarda $(100 ; 0.884)$ \\
\hline RE-04 & Channel catfish (AL) & E. tarda & $2002010013^{a}$ & E. tarda $(\mathrm{N} / \mathrm{A} ; 0.448)$ \\
\hline AL98-87 & Channel catfish (AL) & E. tarda & $2003110113^{a}$ & E. tarda $(98 ; 0.571)$ \\
\hline LADL 88-209 & Hybrid Striped Bass (LA) & E. tarda & $2003110113^{a}$ & E. tarda $(100 ; 0.715)$ \\
\hline FL95-01 & Channel catfish (FL) & E. tarda & $2002010113^{a}$ & E. tarda $(100 ; 0.733)$ \\
\hline LADL 99-302 & Tilapia (LA) & E. tarda & $2002010113^{a}$ & E. tarda $(100 ; 0.634)$ \\
\hline \multicolumn{5}{|l|}{ DNA group II } \\
\hline MA 97-004 & Tilapia (MA) & E. tarda & $2403110113^{\mathrm{a}}$ & E. tarda $(100 ; 0.814)$ \\
\hline S11-285 & Channel catfish (MS) & E. tarda & $2403110113^{a}$ & E. tarda $(93 ; 0.653)$ \\
\hline LADL 97-168 & Channel catfish (LA) & E. tarda & $2403010113^{a}$ & E. tarda $(92 ; 0.658)$ \\
\hline LADL 99-462 & Channel catfish (LA) & E. tarda & $2403010113^{a}$ & E. tarda $(86 ; 0.660)$ \\
\hline S07-346 & Channel catfish (MS) & E. tarda & $2003010103^{a}$ & E. tarda $(99 ; 0.916)$ \\
\hline S07-262 & Channel catfish (MS) & E. tarda & $2003010103^{a}$ & E. tarda $(78 ; 0.751)$ \\
\hline S07-534 & Channel catfish (MS) & E. tarda & $2003110103^{a}$ & E. tarda $(86 ; 0.518)$ \\
\hline S07-275 & Channel catfish (MS) & E. tarda & $2003110103^{a}$ & E. tarda $(98 ; 0.712)$ \\
\hline S07-1019 & Blue catfish (MS) & E. tarda & $2003010113^{a}$ & E. tarda $(100 ; 0.901)$ \\
\hline S07-348 & Channel catfish (MS) & E. tarda & $2403010153^{a}$ & E. tarda $(\mathrm{N} / \mathrm{A} ; 0.492)$ \\
\hline LADL 05-105 & Tilapia (LA) & E. tarda & $2403014113^{a}$ & E. tarda (N/A; 0.468) \\
\hline \multicolumn{5}{|c|}{ Edwardsiella ictaluri } \\
\hline S97-773 & Channel catfish (MS) & No ID & $2002000113^{b}$ & E. ictaluri $(90 ; 0.538)$ \\
\hline S94-711 & Channel catfish (MS) & No ID & $2002000113^{b}$ & $\mathrm{~N} / \mathrm{A}$ \\
\hline S07-698 & Channel catfish (MS) & No ID & $2002000113^{b}$ & $\mathrm{~N} / \mathrm{A}$ \\
\hline
\end{tabular}

\footnotetext{
a Indole + Oxidase -
}

b Indole -; Oxidase 
Table 7

Comparison of characteristics of Edwardsiella tarda isolates from this study. Tests listed in bold differed from the classical description of Edwardsiella tarda (Mohanty and Sahoo, 2007); CyOx = Cytochrome oxidase; VP=Vogues-Proskaueer; ONPG = $\beta$-galactosidase activity.

\begin{tabular}{|c|c|c|c|c|c|c|c|}
\hline & \multicolumn{3}{|c|}{ DNA Group } & & \multicolumn{3}{|c|}{ DNA Group } \\
\hline & I & $\mathrm{II}^{\mathrm{a}}$ & LADL 05-105 & & I & $\mathrm{II}^{\mathrm{a}}$ & LADL 05-105 \\
\hline Gram Stain & - & - & - & Acid from & & & \\
\hline Morphology & $\mathrm{R}$ & $\mathrm{R}$ & $\mathrm{R}$ & Glucose & + & + & + \\
\hline $\mathrm{CyOx}$ & - & - & - & Arabinose & - & - & + \\
\hline TSI & $\mathrm{K} / \mathrm{A}$ & $\mathrm{K} / \mathrm{A}$ & $\mathrm{K} / \mathrm{A}$ & Adonitol & - & - & - \\
\hline $\mathrm{H}_{2} \mathrm{~S}$ on TSI & + & + & + & Cellobiose & - & - & - \\
\hline OF glucose & $\mathrm{Fg}$ & $\mathrm{Fg}$ & $\mathrm{Fg}$ & Dulcitol & - & - & - \\
\hline Motility at $37^{\circ} \mathrm{C}$ & + & + & + & Erythrytol & - & - & - \\
\hline Motility at $25^{\circ} \mathrm{C}$ & + & + & + & Galactose & + & + & + \\
\hline Gelatin & - & - & - & Inositole & - & - & - \\
\hline Indole & + & + & + & Lactose & - & - & - \\
\hline Bile esculine & - & - & - & Maltose & + & + & + \\
\hline Urease & - & - & - & Melibiose & - & - & - \\
\hline Simmon's citrate & - & - & - & Mannitol & - & - & - \\
\hline Phenylalanine & - & - & - & Mannose & + & + & + \\
\hline Nitrate reduction & + & + & + & Rhamnose & - & - & - \\
\hline Methyl Red & + & + & + & Salicin & - & - & - \\
\hline VP & - & - & - & Sorbitol & - & - & - \\
\hline ONPG & - & - & - & Sorbose & - & - & - \\
\hline Malonate & - & - & - & Sucrose & - & - & - \\
\hline Catalase & + & + & + & Trehalose & - & - & - \\
\hline Arginine & - & - & - & Xylose & - & - & - \\
\hline Lysine & + & + & + & & & & \\
\hline Ornithine & + & + & + & Growth in TSB & & & \\
\hline \multirow[t]{2}{*}{ RBC-hemolysis } & $\beta$ & $\beta$ & $\beta$ & $0 \% \mathrm{NaCl}$ & + & + & + \\
\hline & & & & $0.5 \% \mathrm{NaCl}$ & + & + & + \\
\hline Growth at & & & & $1.0 \% \mathrm{NaCl}$ & + & + & + \\
\hline $20^{\circ} \mathrm{C}$ & + & + & + & $1.5 \% \mathrm{NaCl}$ & + & + & + \\
\hline $25^{\circ} \mathrm{C}$ & + & + & + & $2.0 \% \mathrm{NaCl}$ & + & + & + \\
\hline $30^{\circ} \mathrm{C}$ & + & + & + & $2.5 \% \mathrm{NaCl}$ & + & + & + \\
\hline $35^{\circ} \mathrm{C}$ & + & + & + & $3.0 \% \mathrm{NaCl}$ & + & + & + \\
\hline $40^{\circ} \mathrm{C}$ & + & + & + & & & & \\
\hline
\end{tabular}

a Isolate LADL 05-105 was excluded from DNA group II.

\subsection{Biochemical identification, substrate metabolism, FAME analysis and antimicrobial susceptibilty}

All isolates were identified as E. tarda by the $\mathrm{BBL}^{\mathrm{TM}}$ Crystal $^{\mathrm{TM}}$ Enteric/Nonfermenter ID kit, representing 9 different phenotypes based on identification code (Table 6). There is no identification code available for $E$. ictaluri, however, the identification code is consistent with codes seen for E. ictaluri isolates from diseased channel catfish (Griffin, unpublished data). Traditional tests demonstrated the same characteristics for all E. tarda isolates, with the exception of one (LADL 05-105), which produced acid from arabinose (Table 7).

The Biolog system provided different carbon utilization patterns for all $17 \mathrm{E}$. tarda isolates, with $E$. tarda being the closest match for all 17 isolates. The isolates metabolized 29 different substrates; of which no single substrate discriminated between DNA groups (Table 8). In addition, the E. tarda isolates used in this study were relatively homogeneous in regards to cellular fatty acid composition (Table 9) and antimicrobial susceptibility patterns to the chemotherapeutic agents evaluated (data not shown).

\section{Discussion}

With the high degree of phenotypic diversity within bacterial species and the promiscuous nature genetic material is shared between environmental microbes, the accuracy of a biochemical identification can be limited if a large number of isolates have not been tested, especially from phenotypically heterogenous or cryptic genera. As such, current descriptions of bacterial species require both phenotypic and genetic characteristics, although this does little to deconvolute species described prior to the advent of molecular techniques.

The BBL crystal kit provided multiple identification codes for the isolates used in this study; however, the kit offers a multitude of codes for E. tarda, suggesting the existence of numerous phenotypes for this species. Similarly, the Biolog system generated multiple phenotypic profiles for the isolates tested, identifying all 17 isolates as $E$. tarda, although several isolates received low $(<0.50)$ similarity index scores (RE-04; S07-348, LADL 05105). Regardless, metabolic profiles were unable to differentiate between groups. Likewise, biochemical characterization using conventional bacteriology techniques and cellular fatty acid compositions were inconclusive in discriminating between the two genetic groups. Lastly, there were no observable differences between the two groups in terms of antimicrobial susceptibility.

Contradictory to the phenotypic data, genetic fingerprinting by rep-PCR identified two distinct genetic groups within the E. tarda isolates tested. All four primer sets were in agreement with the grouping of isolates, demonstrating 
Table 8

Substrate metabolism for Edwardsiella tarda (ET) isolates; + = positive reaction; - = negative reaction; +1- = borderline positive.

\begin{tabular}{|c|c|c|c|c|c|c|c|c|c|c|c|c|c|c|c|c|c|}
\hline \multirow[t]{2}{*}{ Substrate } & \multicolumn{6}{|c|}{ DNA Group I } & \multicolumn{11}{|c|}{ DNA Group II } \\
\hline & $\begin{array}{l}\text { ATCC } \\
15947\end{array}$ & RE-04 & $\begin{array}{l}\text { AL } \\
98-87\end{array}$ & $\begin{array}{l}\text { LADL } \\
88-209\end{array}$ & $\begin{array}{l}\text { FL } \\
95-01\end{array}$ & $\begin{array}{l}\text { LADL } \\
99-302\end{array}$ & $\begin{array}{l}\text { MA } \\
97-004\end{array}$ & $\begin{array}{l}\text { S11- } \\
285\end{array}$ & $\begin{array}{l}\text { LADL } \\
97-168\end{array}$ & $\begin{array}{l}\text { LADL } \\
99-462\end{array}$ & $\begin{array}{l}\text { S11- } \\
346\end{array}$ & $\begin{array}{l}\text { S07- } \\
262\end{array}$ & $\begin{array}{l}\text { S07- } \\
534\end{array}$ & $\begin{array}{l}\text { S07- } \\
275\end{array}$ & $\begin{array}{l}\text { S07- } \\
1019\end{array}$ & $\begin{array}{l}\text { S07- } \\
348\end{array}$ & $\begin{array}{l}\text { LADL } \\
05-105\end{array}$ \\
\hline Dextrin & - & - & + & $+1-$ & - & + & - & + & + & $+1-$ & $+1-$ & $+1-$ & + & + & + & + & + \\
\hline $\begin{array}{l}\text { N-Acetyl-D- } \\
\text { Glucosamine }\end{array}$ & + & + & + & + & + & + & + & + & + & + & + & $+1-$ & + & + & + & $+1-$ & + \\
\hline D-Fructose & + & + & + & + & + & + & + & + & + & + & + & + & + & + & + & + & + \\
\hline L-Fucose & - & - & - & $+1-$ & - & + & - & - & - & - & - & - & - & - & - & - & - \\
\hline D-Galactose & + & + & + & + & + & + & + & + & $+1-$ & + & + & + & + & + & + & $+1-$ & $+1-$ \\
\hline a-D-Glucose & + & + & + & + & + & + & + & + & + & + & + & $+1-$ & + & + & + & + & + \\
\hline D-Mannose & + & + & + & + & + & - & + & + & + & + & + & + & + & + & + & + & + \\
\hline D-Psicose & + & + & + & + & + & + & - & + & + & - & $+1-$ & - & + & + & $+1-$ & $+1-$ & + \\
\hline $\begin{array}{l}\text { Pyruvic Acid } \\
\text { Methyl Ester }\end{array}$ & $+1-$ & - & + & - & + & + & - & $+1-$ & - & $+1-$ & $+1-$ & $+1-$ & - & - & - & - & - \\
\hline $\begin{array}{l}\text { Succinic Acid } \\
\text { Mono-Methyl Ester }\end{array}$ & - & $+1-$ & + & - & - & + & - & + & - & - & - & - & - & + & - & $+1-$ & + \\
\hline Citric Acid & $+1-$ & + & - & - & $+1-$ & + & - & + & $+1-$ & - & - & - & + & $+1-$ & - & - & $+1-$ \\
\hline D-Gluconic Acid & + & + & + & - & + & + & + & + & - & + & + & + & - & + & + & $+1-$ & $+1-$ \\
\hline D-Clucuronic Acid & $+1-$ & - & - & - & - & - & - & $+1-$ & - & - & - & - & - & - & - & - & + \\
\hline a-Ketoglutaric acid & - & - & + & + & + & + & - & - & - & - & - & - & - & $+1-$ & $+1-$ & - & - \\
\hline D,L-Lactic Acid & + & + & + & + & + & + & + & + & - & - & - & - & - & $+1-$ & + & + & + \\
\hline Succinic Acid & - & $+1-$ & + & - & $+1-$ & + & - & $+1-$ & - & $+1-$ & - & - & - & + & - & + & - \\
\hline Bromosuccinic Acid & - & + & + & + & + & + & - & + & + & - & - & - & - & + & + & + & $+1-$ \\
\hline L-Asparagine & + & + & + & + & + & + & + & + & + & + & + & $+1-$ & + & + & + & + & + \\
\hline L-Aspartic Acid & + & + & + & + & + & + & - & + & + & + & + & $+1-$ & + & + & + & + & + \\
\hline Glycyl-L-Aspartic Acid & + & + & + & + & + & + & + & + & $+1-$ & + & + & $+1-$ & - & + & + & + & + \\
\hline Glycyl-L-Glutamic Acid & - & - & - & - & $+1-$ & - & - & + & - & - & $+1-$ & - & - & + & - & $+1-$ & $+1-$ \\
\hline D-Serine & + & + & + & + & + & + & + & + & + & - & + & - & - & + & + & - & - \\
\hline Inosine & $+1-$ & $+1-$ & - & - & $+1-$ & + & - & $+1-$ & - & - & $+1-$ & - & - & $+1-$ & - & + & - \\
\hline Uridine & + & - & + & + & + & + & - & + & + & - & $+1-$ & $+1-$ & + & + & $+1-$ & + & - \\
\hline Thymidine & + & + & + & + & + & + & - & + & + & - & $+1-$ & $+1-$ & + & + & - & $+1-$ & - \\
\hline Glycerol & + & + & + & + & + & + & + & + & + & + & + & + & - & + & + & + & + \\
\hline D,L,a-glycerol phosphate & + & + & + & $+1-$ & + & + & + & + & - & + & + & + & - & + & $+1-$ & + & $+1-$ \\
\hline a-d-glucose-1-phosphate & + & + & + & + & + & + & + & + & + & + & + & $+1-$ & + & + & + & + & + \\
\hline D-glucose-6-phosphate & + & + & $+1-$ & $+1-$ & + & + & - & + & $+1-$ & + & $+1-$ & $+1-$ & + & + & $+1-$ & $+1-$ & - \\
\hline ID & ET & ET & ET & ET & ET & ET & ET & ET & ET & ET & ET & ET & ET & ET & ET & ET & ET \\
\hline Prob & 100 & - & 98 & 100 & 100 & 100 & 100 & 93 & 92 & 86 & 99 & 78 & 86 & 98 & 100 & - & - \\
\hline Sim & .88 & .448 & .57 & .72 & .73 & .63 & .81 & .65 & .66 & .66 & .92 & .75 & .52 & .71 & .90 & 0.49 & 0.47 \\
\hline
\end{tabular}


Table 9

Comparison of fatty acid composition (\%) from Edwardsiella tarda strains. LADL 05-105 was excluded from DNA Group II.

\begin{tabular}{|c|c|c|c|c|c|c|c|c|c|c|c|c|c|c|c|c|c|c|c|}
\hline & \multicolumn{7}{|c|}{ DNA Group I } & \multicolumn{10}{|c|}{ DNA Group II } & \multirow[b]{2}{*}{ Mean } & \multirow[b]{2}{*}{$\begin{array}{l}\text { LADL } \\
05-105\end{array}$} \\
\hline & $\begin{array}{l}\text { ATCC } \\
15947\end{array}$ & RE-04 & $\begin{array}{l}\text { AL } \\
98-87\end{array}$ & $\begin{array}{l}\text { LADL } \\
88-209\end{array}$ & $\begin{array}{l}\text { FL } \\
95-01\end{array}$ & $\begin{array}{l}\text { LADL } \\
99-302\end{array}$ & Mean & $\begin{array}{l}\text { MA } \\
97-004\end{array}$ & $\begin{array}{l}\text { S11- } \\
285\end{array}$ & $\begin{array}{l}\text { LADL } \\
97-168\end{array}$ & $\begin{array}{l}\text { LADL } \\
99-462\end{array}$ & $\begin{array}{l}\text { S11- } \\
346\end{array}$ & $\begin{array}{l}\text { S07- } \\
262\end{array}$ & $\begin{array}{l}\text { S07- } \\
534\end{array}$ & $\begin{array}{l}\text { S07- } \\
275\end{array}$ & $\begin{array}{l}\text { S07- } \\
1019\end{array}$ & $\begin{array}{l}\text { S07- } \\
348\end{array}$ & & \\
\hline \multicolumn{20}{|l|}{ Fatty Acid (\%) } \\
\hline $12: 0$ & 1.9 & 1.6 & 1.8 & 1.9 & 1.9 & 1.7 & 1.8 & 0.6 & 0.6 & 0.6 & 0.6 & 0.6 & 0.6 & 0.6 & 0.6 & 0.6 & 0.6 & 0.6 & 0.8 \\
\hline $13: 0$ & 0.6 & 0.4 & 0.4 & 0.4 & 0.4 & 0.4 & 0.4 & 0.4 & 0.7 & 0.4 & 0.5 & 0.5 & 0.5 & 0.5 & 0.6 & 0.4 & 0.5 & 0.5 & - \\
\hline $12: 030 \mathrm{H}$ & - & - & - & 0.09 & - & - & - & - & 0.1 & 0.1 & 0.1 & 0.1 & 0.1 & 0.1 & 0.1 & 0.1 & 0.1 & - & - \\
\hline $14: 0$ & 12.6 & 12.7 & 11.1 & 13.3 & 12.4 & 11.7 & 12.3 & 13.4 & 14.8 & 12.6 & 14.4 & 15.8 & 14.2 & 14.4 & 14.2 & 14.5 & 14.1 & 14.2 & 16.6 \\
\hline $15: 1 \mathrm{w} 8 \mathrm{c}$ & 0.1 & 0.1 & - & - & - & - & - & 0.1 & 0.1 & 0.1 & 0.1 & 0.1 & 0.1 & 0.1 & 0.1 & 0.1 & 0.1 & 0.1 & - \\
\hline $15: 030 \mathrm{H}$ & - & - & - & - & - & - & _- & 0.1 & 0.2 & 0.1 & 0.1 & 0.1 & 0.1 & 0.1 & 0.2 & 0.1 & 0.1 & 0.1 & _- \\
\hline $16: 1 \mathrm{w} 5 \mathrm{c}$ & 0.2 & 0.3 & 0.2 & 0.2 & 0.2 & 0.2 & 0.2 & 0.2 & 0.2 & 0.2 & 0.2 & 0.2 & 0.2 & 0.2 & 0.2 & 0.2 & 0.2 & 0.2 & 0.2 \\
\hline $16: 0$ & 33.6 & 34.0 & 34.5 & 36.3 & 35.7 & 35.7 & 35.0 & 34.0 & 34.5 & 32.7 & 33.5 & 33.7 & 34.9 & 34.9 & 34.0 & 34.7 & 34.8 & 34.1 & 37.4 \\
\hline 17:0 anteiso & - & - & - & - & - & - & - & - & - & - & - & - & - & - & - & 0.04 & 0.05 & - & - \\
\hline $17: 0$ iso & - & - & 0.2 & - & - & - & - & - & 0.1 & 0.1 & - & 0.1 & - & 0.1 & 0.1 & 0.1 & 0.1 & - & - \\
\hline $17: 1 \mathrm{w} 8 \mathrm{c}$ & 0.4 & 0.3 & 0.3 & - & - & 0.3 & - & 0.4 & 0.4 & 0.4 & 0.4 & 0.4 & 0.3 & 0.3 & 0.4 & 0.3 & 0.4 & 0.4 & - \\
\hline 17:0 cyclo & 16.3 & 16.8 & 8.2 & 19.3 & 17.5 & 10.8 & 14.8 & 13.2 & 14.9 & 17.2 & 14.2 & 15.7 & 16.0 & 17.1 & 16.0 & 16.0 & 16.2 & 15.7 & 11.2 \\
\hline $17: 0$ & 1.23 & 0.7 & 0.7 & 0.6 & 0.8 & 0.6 & 0.8 & 0.9 & 0.9 & 1.3 & 1.0 & 0.9 & 0.7 & 0.6 & 1.0 & 0.6 & 0.7 & 0.9 & 0.4 \\
\hline $18: 1 \mathrm{w} 6 \mathrm{c}$ & 0.3 & 0.2 & - & - & 0.2 & - & - & 0.2 & 0.2 & 0.3 & 0.2 & 0.2 & 0.2 & 0.1 & 0.2 & 0.2 & 0.2 & 0.2 & - \\
\hline $18: 1$ w9c & 1.6 & 2.0 & 1.9 & 1.7 & 1.6 & 2.2 & 1.9 & 1.5 & 1.9 & 2.0 & 1.6 & 2.0 & 1.8 & 1.8 & 2.0 & 1.7 & 1.7 & 1.8 & 2.0 \\
\hline $18: 0$ & 1.5 & 1.7 & 1.5 & 1.6 & 1.4 & 1.7 & 1.8 & 1.3 & 1.4 & 1.5 & 1.2 & 1.4 & 1.5 & 1.5 & 1.4 & 1.3 & 1.4 & 1.4 & 1.4 \\
\hline $18: 1 \mathrm{w} 7 \mathrm{c}$ & 3.8 & 3.7 & 6.9 & 2.8 & 3.5 & 6.4 & 4.5 & 6.0 & 4.4 & 5.8 & 5.1 & 4.2 & 4.5 & 4.4 & 4.9 & 4.7 & 4.5 & 4.8 & 2.8 \\
\hline 19:0 cyclo w8c & 2.6 & 2.4 & 0.5 & 3.3 & 3.4 & 0.9 & 2.2 & 1.1 & 1.2 & 2.0 & 1.1 & 1.3 & 1.2 & 1.4 & 1.4 & 1.2 & 1.3 & 1.3 & 1.3 \\
\hline $19: 0$ & 0.4 & 0.3 & 0.2 & 0.4 & 0.4 & 0.2 & 0.3 & 0.2 & 0.3 & 0.3 & 0.3 & 0.3 & 0.2 & 0.2 & 0.3 & 0.2 & 0.2 & 0.3 & - \\
\hline $20: 4$ w6,9,12,15c & 0.4 & 0.5 & 0.4 & 0.4 & 0.3 & 0.4 & 0.4 & 0.4 & 0.3 & 0.4 & 0.4 & 0.4 & 0.4 & 0.5 & 0.3 & 0.3 & 0.4 & 0.4 & 0.3 \\
\hline \multicolumn{20}{|l|}{ Summed features } \\
\hline 2 & 9.4 & 9.0 & 8.8 & 8.9 & 9.2 & 8.1 & 8.9 & 8.5 & 8.5 & 8.8 & 8.6 & 8.8 & 8.4 & 8.4 & 8.2 & 8.3 & 8.6 & 8.5 & 9.0 \\
\hline 3 & 11.0 & 1.3 & 20.8 & 6.8 & 8.3 & 16.9 & 10.9 & 16.2 & 12.4 & 10.9 & 14.7 & 11.3 & 12.3 & 10.8 & 11.9 & 12.5 & 12.0 & 12.5 & 14.1 \\
\hline 5 & 2.0 & 2.0 & 1.8 & 2.1 & 2.0 & 1.8 & 1.9 & 1.6 & 1.8 & 2.1 & 1.7 & 2.0 & 1.7 & 1.7 & 1.9 & 1.7 & 1.7 & 1.8 & 2.0 \\
\hline 8 & 4.0 & 3.9 & 6.9 & 2.8 & 3.6 & 6.4 & 4.6 & 6.1 & 4.6 & 6.1 & 5.2 & 4.4 & 4.7 & 4.5 & 5.1 & 4.8 & 4.7 & 5.0 & 2.8 \\
\hline Sim Index to $E$. tarda & 0.77 & 0.77 & 0.87 & 0.89 & 0.86 & 0.68 & 0.81 & 0.57 & 0.64 & 0.7 & 0.48 & 0.70 & 0.66 & 0.75 & 0.68 & 0.64 & 0.68 & 0.65 & $<0.3$ \\
\hline
\end{tabular}


remarkable differences ( $<40 \%$ similarity) between DNA groups I and II. Although banding patterns for respective primer sets varied in complexity, all primer sets demonstrated substantial differences between the two main groups. Isolate LADL 05-105, likely a genetic variant, consistently grouped outside of DNA group II, although this isolate shared more similarities with DNA group II and $E$. ictaluri then DNA group I.

Similarly, fluorometric estimation of $\mathrm{G}+\mathrm{C}$ content identified marked differences between DNA group I and DNA group II, with all isolates from DNA group I demonstrating melting temperatures 1-2 degrees lower than DNA group II. This difference in melting temperatures represents an approximate difference in $G+C$ content of nearly $4 \%$, with both groups of $E$. tarda demonstrating more similar $G+C$ ratios to $E$. ictaluri than to each other.

This study also demonstrates the limitations of using 16S SSU sequencing for bacterial identification, which has been well reviewed (Fox et al., 1992; Janda and Abbott, 2002; Clarridge, 2004). In general, a range of about $0.5-1 \%$ difference (99-99.5\% similarity) is often used as a cutoff for species discrimination, although there are several instances where even a $1 \%$ difference is overly conservative (Clarridge, 2004). Because the 165 SSU gene is so highly conserved, multilocus sequence typing has been proposed as an alternative method of genetic characterization (Cooper and Feil, 2004). Although the E. tarda groups in this study demonstrate greater than 99\% similarity between them ( 1300 bp) at the 16S SSU locus, DNA group II is more similar to E. ictaluri than DNA group I at every other target used in the analysis. In addition, DNA groups I and II share less than $90 \%$ similarity at several targets (GyrA, GyrB, Pho, Pgi, Pgm).

Phylogenetic analysis consistently separated the two $E$. tarda groups, placing members of DNA group I in their own distinct cluster with high bootstrap support (range 97$100 \%$ ). Regardless of gene target, phylogram topographies repeatedly placed $E$. ictaluri sister to DNA group II as part of a larger cluster sister to DNA group I. This data suggests a monophyletic origin for the three species of bacteria (DNA group I, DNA group II and E. ictaluri), which likely arose from a single common ancestor, with DNA group II and $E$. ictaluri diverging in a later event. The significant genetic separation between DNA group I and DNA group II, and the fact DNA group II shares greater similarity to E. ictaluri than to DNA group I, suggests these two DNA groups are not conspecific. This supports similar findings in China, where comparative phylogenomics and multilocus sequencing identified two distinct genetic groups of E. tarda (Yang et al., 2012) and is in agreement with other studies (Castro et al., 2006; Panangala et al., 2006; Acharya et al., 2007; Maiti et al., 2008; Maiti et al., 2009; Castro et al., 2011; Wang et al., 2011).

The data presented here also clarifies why a definitive diagnostic PCR for E. tarda has yet to be developed. There have been several attempts to develop a PCR assay for the detection of $E$. tarda from a wide variety of substrates, with mixed results. Chen and Lai (1998) initially developed a PCR for the detection of the Hemolysin gene (GenBank L43071) of E. tarda from infected fish and environmental samples. Their PCR amplified the appropriate sized amplicon from 40 different E. tarda isolates. However, none of the isolates used in the current study were positive by this PCR, suggesting this primer set is specific to a different E. tarda variant.

Similarly, Sakai et al. (2007) developed primers specific to subunits of the type 1 fimbrial genes $E$. tarda isolates from different species of fish. They found primer sets EtfimA and EtfimD produced PCR products of the appropriate size from all 17 pathogenic isolates examined; however, there was inconsistent amplification from nonpathogenic isolates and the EtfimD produced false positives from E. ictaluri. A follow up study developed two new primer sets that separated E. tarda isolates into two groups, typical (Ettyp) and atypical (Etatyp) (Sakai et al., 2009); however, data presented here suggests typical and atypical isolates both fall into DNA group II.

Similarly, Lan et al. (2008) attempted to amplify the GyrB gene from a non-motile E. tarda isolated from turbot in Japan. The assay produced the desired product in 20 of 68 isolates, all of which were identified as $E$. tarda biochemically and by $16 \mathrm{~S}$ SSU sequence. In the development of this PCR the gyrB genes of 3 separate isolates were sequenced and deposited into GenBank (EU259315, EU259316, and EU259317), all of which fall into DNA group II. Unfortunately, the gyrB sequences of the isolates that were PCR negative were not sequenced.

More recently, the above mentioned primer sets were comparatively evaluated for their ability to detect $E$. tarda in turbot (Castro et al., 2010). They evaluated 53 different isolates of E. tarda, confirmed biochemically and serologically, as well as 18 isolates from other bacterial strains isolated from an array of fish hosts. Contradictory to our findings, 11 of the $53 \mathrm{E}$. tarda isolates and $1 \mathrm{E}$. ictaluri isolate were positive for the hemolysin gene targeted by the primers of Chen and Lai (1998), whereas none of the isolates were positive for the gyrB primers of Lan et al. (2008). The EtfimA primers and EtfimD primers of Sakai et al. (2007) were the most consistent, with 49 of the 53 tarda isolates positive using the EtfimA primers, although these primers also amplified target DNA from E. ictaluri, $E$. hoshinae, E. coli, Enterobacter aerogenes, Aeromonas salmonicida ssp. Salmonicida and two isolates of Yersinia ruckeri. Conversely, all 53 isolates of E. tarda were amplified by the EtfimD primers, with no amplification of other bacterial strains.

It should be noted that all of the above mentioned PCR assays are valid for their respective isolates; however, sequence data is unavailable for most isolates used in the validation of these assays. While the best efforts were made to mimic the original conditions of the PCR, many factors could explain the variable results demonstrated here and in other studies, most notably the intraspecific variability of E. tarda. Further compounding the problem of a species-specific PCR is that one group of E. tarda (DNA group II) shares a greater degree of genetic similarity with E. ictaluri than other E. tarda strains. As such, the development of a PCR specific to all E. tarda but discriminatory against $E$. ictaluri will be unlikely. Though identified biochemically as E. tarda, it is evident the isolates used in these studies do not share the same genetic composition and possibly represent two genetically 
distinct taxa. Although our current research identifies only two distinct genotypes, it is possible more exist. The data generated here will be utilized in the development of more accurate molecular diagnostics to better understand the role these genetically distinct $E$. tarda groups play in fish health.

\section{Acknowledgements}

The authors would like to thank Stephen Reichley and Drew Leach for their technical contributions to this manuscript. In addition, the authors would like to thank Andrew Goodwin of the University of Arkansas-Pine Bluff, Cova Arias, Mark Liles, and Jeff Terhune of Auburn University and John Hawke of Louisiana State University for their willingness to share bacterial isolates. This research was funded through the USDA Catfish Health Research Initiative (CRIS 6402-31320-002-02) and is supported by the Mississippi State University College of Veterinary Medicine and Mississippi Agricultural and Forestry Experiment Station (MAFES). This is MAFES publication number $\mathrm{J}-12272$.

\section{References}

Acharya, M., Maiti, N.K., Mohanty, S., Mishra, P., Samanta, M., 2007. Genotyping of Edwardsiella tarda isolated from freshwater culture system. Comp. Immunol. Microbiol. Infect. Dis. 30, 33-40.

Castro, N., Toranzo, A.E., Barja, J.L., Núñez, S., Magariños, B., 2006. Characterization of Edwardsiella tarda strains isolated from turbot, Psetta maxima (L.). J. Fish Dis. 29, 541-547.

Castro, N., Toranzo, A.E., Núñez, S., Osorio, C.R., Magariños, B., 2010. Evaluation of four polymerase chain reaction primer pairs for the detection of Edwardsiella tarda in turbot. Dis. Aquat. Organ. 18, 55-61.

Castro, N., Toranzo, A.E., Bastardo, A., Barja, J.L., Magariños, B., 2011. Intraspecific genetic variability of Edwardsiella tarda strains from cultured turbot. Dis. Aquat. Organ. 95, 253-258.

Chen, J.D., Lai, S.Y., 1998. PCR for direct detection of Edwardsiella tarda from infected fish and environmental water by application of the hemolysin gene. Zool. Stud. 37, 169-176.

Clarridge, J.E., 2004. Impact of 16S rRNA gene sequence analysis for identification of bacteria on clinical microbiology and infectious diseases. Clin. Microbiol. Rev. 17, 840-862.

Cooper, J.E., Feil, E.J., 2004. Multilocus sequence typing-what is resolved? Trends Microbiol. 12, 373-377.

Ewing, W.H., Mcwhorter, A.C., Escobar, M.R., Lubin, A.H., 1965. Edwardsiella, a new genus of Enterobacteriaceae based on a new species, $E$. tarda. Int. J. Syst. Evol. Microbiol. 15, 33-38.

Felsentein, J., 1985. Confidence limits on phylogenies: an approach using the bootstrap. Evolution 39, 783-791.

Fox, G.E., Wisotzkey, J.D., P. Jurtshuk, P.J.R., 1992. How close is close: 16S rRNA sequence identity may not be sufficient to guarantee species identity. Int. J. Syst. Bacteriol. 42, 166-170.

Gonzalez, J.M., Saiz-Jimenez, C., 2002. A fluorimetric method for the estimation of $\mathrm{G}+\mathrm{C}$ mol\% content in microorganisms by thermal denaturation temperature. Environ. Microbiol. 4, 770-773.

Griffin, M.J., Mauel, M.J., Greenway, T.E., Khoo, L.H., Wise, D.J., 2011. A real-time polymerase chain reaction assay for quantification of Edwardsiella ictaluri in catfish pond water and genetic homogeneity of diagnostic case isolates from Mississippi. J. Aquat. Anim. Health. 23, $178-188$.

Hawke, J.P., Khoo, L.H., 2004. Infectious diseases. In: Tucker, C.S., Hargreaves, J.A. (Eds.), Biology and Culture of the Channel Catfish. Elsevier B.V., Amsterdam, The Netherlands, pp. 387-443.

Janda, J.M., Abbott, S.L., 2002. Bacterial identification for publication: when is enough enough? J. Clin. Microbiol. 40, 1887-1891.
Kimura, M., 1980. A simple method for estimating evolutionary rate of base substitutions through comparative studies of nucleotide sequences. J. Mol. Evol. 16, 111-120.

Lan, J., Zhang, X.H., Wang, Y., Chen, J., Han, Y., 2008. Isolation of an unusual strain of Edwardsiella tarda from turbot and establish a PCR detection technique with the gyrB gene. J. Appl. Microbiol. 105, 644-651.

Lennette, E.H., Ballows, A., Hauser Jr., W.J., Shadomy, H.J., 1985. Manual of Clinical Microbiology, 4th edition. American Society for Microbiology, Washington, DC 1149 pp.

MacFaddin, J.F., 1981. Biochemical Tests for Identification of Medical Bacteria, 2nd edition. Williams and Wilkins, Baltimore/London 527 pp.

Maiti, N.K., Mandal, A., Mohanty, S., Samanta, M., 2008. Comparative analysis of genome of Edwardsiella tarda by BOX-PCR and PCR-ribotyping. Aquaculture 280, 60-63.

Maiti, N.K., Mandal, A., Mohanty, S., Mandal, R.N., 2009. Phenotypic and genetic characterization of Edwardsiella tarda isolated from pond sediments. Comp. Immunol. Microb. 32, 1-8.

Meyer, F.P., Bullock, G.L., 1973. Edwardsiella tarda, a new pathogen of channel catfish (Ictalurus punctatus). Appl. Microbiol. 25, 155-156.

Mohanty, B.R., Sahoo, P.K., 2007. Edwardsiellosis in fish: a brief review. J. Biosci. 32, 1331-1344

Panangala, V.S., Shoemaker, C.A., McNulty, S.T., Arias, C.R., Klesius, P.H. 2006. Intra- and interspecific phenotypic characteristics of fishpathogenic Edwardsiella ictaluri and E. tarda. Aquacult. Res. 37, 49-60.

Rainey, F.A., Ward-Rainey, N.L., Janssen, P.H., Hippe, H., Stackebrandt, E., 1996. Clostridium paradoxum DSM $7308^{\mathrm{T}}$ contains multiple $16 \mathrm{~S}$ rRNA genes with heterogenous intervening sequences. Microbiology 142, 2087-2095.

Saitou, N., Nei, M., 1987. The neighbor-joining method: a new method for reconstructing phylogenetic trees. Mol. Biol. Evol. 4, 406-425.

Sakai, T., Iida, T., Osatomi, K., Kanai, K., 2007. Detection of Type 1 fimbrial genes in fish pathogenic and non-pathogenic Edwardsiella tarda strains by PCR. Fish Pathol. 42, 115-117.

Sakai, T., Yuasa, K., Sano, M., Iida, T., 2009. Identification of Edwardsiella ictaluri and E. tarda by species-specific polymerase chain reaction targeted to the upstream region of the fimbrial gene. J. Aquat. Anim. Health. 21, 124-132.

Sasser, M., 1990. Identification of bacteria by gas chromatography of cellular fatty acids. MIDI Technical Note 101. MIDI Inc., Newark, Delaware.

Tamura, K., Peterson, D., Peterson, N., Stecher, G., Nei, M., Kumar, S., 2011. MEGA5: molecular evolutionary genetics analysis using maximum likelihood, evolutionary distance, and maximum parsimony methods. Mol. Biol. Evol. 28, 2731-2739.

van Soest, J., Stockhammer, O.W., Ordas, A., Bloemberg, G.V., Spaink, H.P. Meijer, A.H., 2011. Comparison of static immersion and intravenous injection systems for exposure of zebrafish embryos to the natural pathogen Edwardsiella tarda. BMC Immunobiol. 12, 58, http:// dx.doi.org/10.1186/1471-2172-12-58.

Versalovic, J., Koeuth, T., Lupski, J.R., 1991. Distribution of repetitive DNA sequences in eubacteria and application to fingerprinting of bacterial genomes. Nucleic Acids Res. 19, 6823-6831.

Versalovic, J., Schneider, M., de Bruijn, F.J., Lupski, J.R., 1994. Genomic fingerprinting of bacteria using repetitive sequence-based polymerase chain reaction. Method Mol. Cell. Biol. 5, 25-40.

Wang, Q., Yang, M., Xiao, J., Wu, H., Wang, X., Lv, Y., Xu, L., Zheng, H., Wang, S., Zhao, G., Liu, Q., Zhang, Y., 2009. Genome sequence of the versatile fish pathogen Edwardsiella tarda provides insights into its adaptation to broad host ranges and intracellular niches. PLoS ONE 4, e7646, http://dx.doi.org/10.1371/journal.pone.0007646.

Wang, Y.M., Wang, Q.Y., Xiao, J.F., Liu, Q., Wu, H.Z., Zhang, Y.X., 2011. Genetic relationships of Edwardsiella strains isolated in China aquaculture revealed by rep-PCR genomic fingerprinting and investigation of Edwardsiella virulence genes. J. Appl. Microbiol. 111, 1337-1348.

Williams, M.L., Gillaspy, A.F., Dyer, D.W., Thune, R.L., Waldbieser, G.C., Schuster, S.C., Gipson, J., Zaitshik, J., Landry, C., Banes, M.M., Lawrence, M.L., 2012. Genome sequence of Edwardsiella ictaluri 93-146, a strain associated with a natural channel catfish outbreak of enteric septicemia of catfish. J. Bacteriol. 194, 740-741.

Yang, M., Lv, Y., Xiao, J., Wu, H., Zheng, H., Liu, Q., Zhang, Y., Wang, Q., 2012 Edwardsiella comparative phylogenomics reveal the new intra/interspecies taxonomic relationships, virulence evolution and niche adaptation mechanisms. PLoS ONE 7 (5) e36897. 